\title{
RESEARCH
}

Open Access

\section{Mixed-unit hybrid life cycle assessment applied to the recycling of construction materials}

\author{
Soo Huey Teh ${ }^{1 *}$, Thomas Wiedmann ${ }^{1,2}$ and Stephen Moore ${ }^{1}$
}

\author{
*Correspondence: \\ soohuey.teh@unsw.edu.au \\ ${ }^{1}$ Sustainability Assessment \\ Program (SAP), School \\ of Civil and Environmental \\ Engineering, University \\ of New South Wales, Sydney, \\ NSW 2052, Australia \\ Full list of author information \\ is available at the end of the \\ article
}

\begin{abstract}
The construction industry contributes around 18\% of greenhouse gas emissions, $40 \%$ of depletion of natural resources, and $25 \%$ of wastes globally. To reduce these impacts, construction industries can adopt low-carbon alternatives for construction materials and waste minimisation strategies, including the recycling of construction and demolition waste. However, a comprehensive understanding of the full life cycle carbon profile of low-carbon and recyclable construction materials is required to accurately assess the efficacy of decarbonisation strategies in the built environment. Despite recent progress in hybrid life cycle assessment (hybrid LCA) methods, some weaknesses remain with respect to the inherent uncertainty relating to price variations and aggregated sectors that are unable to provide detailed waste-specific information in hybrid LCA. Furthermore, attributional, hybrid LCA for a functional unit does not reflect the actual, economy-wide physical flows of materials in a real economy. In this study, a mixed-unit hybrid LCA approach based on a combination of process life cycle inventory, input-output, and material flow data is used to model the economy-wide potential use of recycled construction materials in Australia. A comparison between methods of life cycle emissions of geopolymer concrete revealed that the mixed-unit hybrid LCA approach produced a more accurate and Australian-specific result. The usefulness of the proposed mixed-unit 10 model is demonstrated through quantifying the cradle-togate embodied emissions of recycled construction materials and by-products utilised in concrete and steel sectors in Australia. The results yield a 1\% reduction when recycled concrete aggregate completely replaces natural aggregate in both ordinary Portland cement and geopolymer concrete. Greenhouse gas emissions reduction of 30\% is quantified for geopolymer concrete using recycled concrete aggregate compared with ordinary Portland cement concrete utilising natural aggregate and $43 \%$ is estimated for electric arc furnace route using iron and steel scrap compared with basic oxygen furnace route. The method merges physical and monetary units of industrial systems related to low-carbon alternatives and recycled construction materials to enable the calculations of embodied carbon with improved accuracy. The results of this study can help inform decarbonisation strategies in the built environment sector.
\end{abstract}

Keywords: Hybrid LCA, Material flow analysis (MFA), Mixed-unit input-output model, Concrete, Steel, Recycling, Recycled concrete aggregate 


\section{Background}

The construction industry is responsible for about $18 \%$ of greenhouse gas emissions (GHGE), $40 \%$ of depletion of natural resources, and 25\% of wastes worldwide (Ding 2014; Yu et al. 2017). Hence, it is important that sustainable alternatives and practices are explored in order to reduce the industry's environmental impacts. Low-carbon alternatives for construction materials and waste minimisation strategies, such as recycling construction and demolition (C\&D) waste, are ways for the construction industry to contribute to a more sustainable development in the wider economy. However, only a comprehensive quantitative evaluation can assess whether the actual benefits of lowcarbon and recycled construction materials are realised if the whole life cycle of all processes is taken into account. One of the main disadvantages of input-output table (IOT) is that it does not consider the end-of-life phase, which includes recycling (Nakamura and Nansai 2016). Therefore, a suitable method is needed to capture the full, economywide carbon profile of alternative construction materials and practices.

The most widely used method to assess the impacts of construction materials is process-based life cycle assessment (LCA). LCA provides material-specific data, but suffers from having an incomplete system boundary, which can lead to an underestimation of the impacts assessed (Crawford 2008; Crawford et al. 2018; Wan Omar et al. 2014). On the other hand, input-output analysis (IOA) offers economy-wide system boundary completeness, based on inter-industry monetary flow data, but has limitations relating to price variability, sector aggregation, and the lack of material-specific data (Dixit 2017; Säynäjoki et al. 2017).

In a pure monetary input-output table (MIOT), the direct and indirect interdependencies of sectors are captured in monetary units (e.g. dollars), and monetary data are readily available. However, as the prices of physical products vary between different sectors, the assumption that the physical quantity transactions between sectors are proportional to their monetary values leads to an erroneous allocation of environmental impacts in the standard MIOT model (Lenzen 2000; Vendries Algarin et al. 2016). Furthermore, economies of scale means that the per unit monetary value of production outputs vary with their physical quantities (Bullard and Herendeen 1975).

The issue of price variability and heterogeneity can be avoided by replacing monetary units with actual material production and consumption flows in physical units. Physical input-output table (PIOT) is expressed only in physical units, showing the flows of physical products across sectors and their interaction with the environment, as well as accounting for waste flows (Giljum and Hubacek 2004; Hoekstra and van den Bergh 2006). PIOT is superior in representing mass flows, but is instead unable to capture monetary flows in the economy for service-based sectors. Data to construct PIOT are also often scarce, conflicting, and labour-intensive, resulting in a limited number of aggregated tables constructed with low resolution (Altimiras-Martin 2014).

In addition to price variation, other reasons for differences in results between MIOT and PIOT approaches, as identified by Giljum and Hubacek (2004), Liang and Zhang (2013) and Weisz and Duchin (2006), include assumptions relating to unique sector prices, level of sector aggregation, the models' capability of dealing with service sectors, accounting for waste, and estimating residential consumption. Hence, the selection of an appropriate unit type is an important decision. 
A 'hybrid' approach constitutes either the utilisation of both monetary and physical units, or the amalgamation of process and input-output (IO) data (Suh et al. 2004). With the former, information gaps can be completed with the more suitable data type (e.g. unit mass for raw materials, and unit dollar for services). The removal of the price conversion step in calculating commodity costs also reduces inaccuracies associated with methods of approximation. In terms of data, process-based life cycle inventory (LCI) data provide specific sector resolution and physical ingredients for the manufacture of a product, whilst economy-wide IO data capture the monetary inter-dependencies of industry sectors, and economy-wide material flow analysis (MFA) data capture the total quantity of material flow used by an industry sector.

The confluence between combining physical with monetary units and amalgamating process LCI, IO and material flow data (Fig. 1) leads to the mixed-unit hybrid life cycle assessment (MU-hLCA) framework (Hawkins et al. 2007; Hawkins 2007), which can be seen as equivalent to the integrated hLCA in Suh (2004). The advantage of this method is that it combines the precision of process-based MFA, the detailed sector resolution of LCI, and the comprehensiveness of IOA. It adds missing upstream supply chains to the MFA component, whilst also resolving the price variability issue by introducing physical units into the model. By doing so, all phases of the product life cycle including the use, disposal, and recycling stages can be examined. To date, various mixed-unit input-output table (MUIOT) approaches have been used, including extended IO models for energy and emissions (Mayer and Flachmann 2011), integrated hLCA to track heavy metals sectors (Hawkins et al. 2007; Hawkins 2007), ecological IOA in modelling energy and material flows through an industrial system (Bailey et al. 2004), and multi-layered MUIOT, which utilises the mass, energy, and monetary layers (Majeau-Bettez et al. 2016).

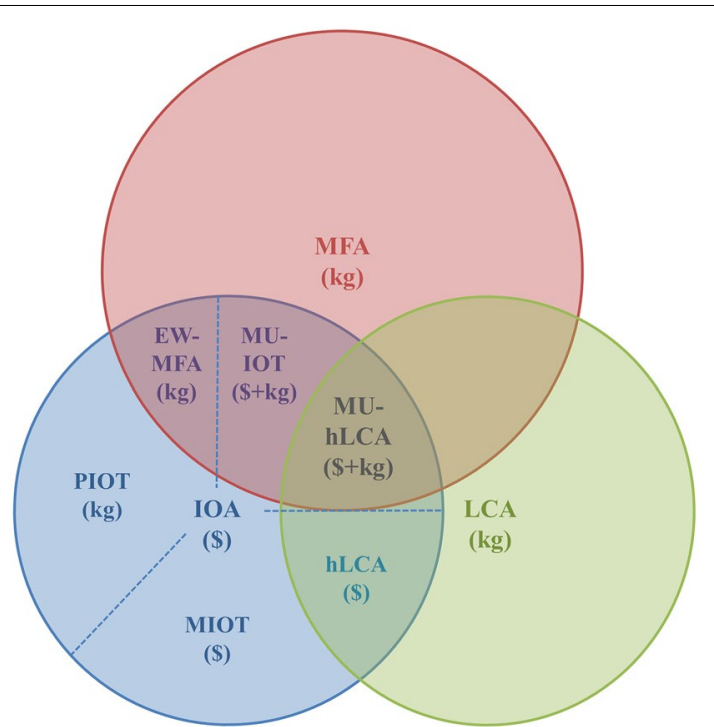

Fig. 1 Relationship of methods and proposed methodology of MU-hLCA (EW-MFA economy-wide material flow analysis) 
In this study, MU-hLCA is employed in a case study on geopolymer concrete (GPC) and compared to published results from process-based and IO-based methods. The usefulness of MU-hLCA is demonstrated through its application in modelling an economywide potential use of recycled construction materials in Australia. The proposed model merges physical and monetary units of industrial systems related to construction materials and their recycled substitute products in order to enable the calculations of embodied carbon and the tracking of material flows with improved accuracy. The results of this study will help inform decarbonisation strategies in the built environment sector.

This study is the first to model recycled construction materials on an economy-wide scale via a MU-hLCA framework that utilises Australian-specific LCI and IO databases. The novel features of this study are described in the implementation steps taken as outlined below:

1. modelling recycled construction materials in a MU-hLCA framework;

2. economy-wide scale use of specific materials;

3. use of an Australian-specific database (AusLCI 2015) in the MU-hLCA framework; and.

4. applying a decomposition method adapted from Wiedmann (2017) for process, products and industries.

The concrete case study from Teh et al. (2017) is advanced in this study to quantify life cycle embodied emissions of concrete and steel incorporating recycled construction materials.

\section{Application of MU-hLCA}

\subsection{Aim and scope}

The goal of this study is primarily to compare the results of the MU-hLCA approach with that of input-output-based hybrid life cycle assessment (IO-hLCA) and LCA using GPC as a case study. Secondly, the application and the usefulness of the MU-hLCA method are demonstrated through modelling the use of recycled materials and by-products in concrete and steel, specifically via comparing the carbon footprint intensity (CFI) in the following scenarios:

1. Ordinary Portland cement concrete (with natural aggregate) versus ordinary Portland cement concrete (with recycled concrete aggregate);

2. Fly ash-based GPC concrete (with fly ash, slag, and natural aggregate) versus fly ashbased GPC concrete (with fly ash, slag and recycled concrete aggregate); and

3. Basic oxygen furnace steel versus electric arc furnace steel (with iron and steel scrap).

\subsection{Modelling recycling of construction waste}

It is vital for the construction industry to recycle $C \& D$ waste as the industry consumes a large amount of natural resources. C\&D waste accounts for approximately 40\% (19 Mt) of total solid waste in Australia (47 Mt) (Hyder Consulting 2011a, b; Productivity Commission 2006), of which $45 \%$ is disposed to the landfill and 55\% is recycled (Hyder Consulting 2011a) (in 2008-2009). The C\&D waste stream is composed of masonry materials 
(concrete, bricks, asphalt, etc.), metals (steel, non-ferrous, etc.), organics, paper and cardboard, plastics, glass, leather and textiles, tyres and hazardous substances. Masonry waste (which includes concrete, bricks, asphalt, etc.) constitutes the greatest proportion in the C\&D waste stream at $89 \%$ (15 Mt), but only $62 \%$ (9 Mt) is currently being recycled (Hyder Consulting 2011a). In comparison, metal constitutes only around 20\% (951 kt) of the C\&D waste, but has a much higher recycling rate of $87 \%$ (831 kt) (Hyder Consulting 2011a). Concrete and steel are chosen as case studies because (1) global aggregate production has doubled from 21 to $40 \mathrm{Gt}$ (from 2007 to 2014) leading to a growing issue of scarcity in landfill space and aggregates (Tam et al. 2018; Torres et al. 2017), and (2) concrete and steel are major contributors to climate change, each accounting for 56 and $6 \%$ of 30 Mt of Australian building products produced annually (Miller et al. 2015).

Impacts of construction materials that incorporate recycled products have been assessed with process-based LCA in many studies, for example concrete (Braunschweig et al. 2011; Kleijer et al. 2017; Knoeri et al. 2013; Marinković et al. 2010; Shan et al. 2017; Tošić et al. 2015) and steel (Burchart-Korol 2013; Norgate et al. 2007; Olmez et al. 2016). At the same time, few studies have used IO-based hLCA (Choi et al. 2011; Kucukvar et al. 2014; Teh et al. 2017; Wijayasundara et al. 2017a). Kucukvar et al. (2014) combined process-based LCA with IOA to assess the onsite impacts and higher order supply chain impacts of recycling, incineration and landfilling of C\&D waste. Wijayasundara et al. (2017a) compared the embodied energy of recycled aggregate concrete and natural aggregate concrete in Australia using the IO-based hLCA method. Choi et al. (2011) analysed the economic impact of localised e-waste recycling using an extended IO model by (2) reconstructing the IO table and satellite environmental account to describe e-waste recycling sectors, and (2) monetising physical e-waste flows in a consistent manner. So far, no studies have been conducted using MU-hLCA to model an economy-wide scale of recycled construction materials.

One of the disadvantages specific to the application of recycled products in the IO framework is that waste is an aggregated sector, which is labelled "Waste collection, treatment and disposal services" in the Australian IOT, and does not provide detailed, waste-specific information. Recycling industries and their accompanying products are also not captured in detail and are sometimes represented as part of the main waste sector (Choi et al. 2011). Secondly, waste services are rendered in monetary units, i.e. in terms of service fees, and do not equate to the actual physical amounts of waste generated (Liang and Zhang 2013).

A framework known as the waste input-output (WIO) model, which specifically analyses waste types and treatment flows using an extended IOT method, was developed by Nakamura and Kondo (2002, 2009). Using the WIO model, Nakamura and Kondo (2006) evaluated the economic and environmental impacts of waste treatment methods and recycling of electrical appliances in Japan. The WIO model was subsequently applied to calculate waste multipliers and footprints in Australia (Fry et al. 2016; Lenzen and Reynolds 2014; Reynolds et al. 2014). This study offers an alternative approach, by using a MU-hLCA framework where waste flows can be represented in physical units, and specific products including, but not limited to, by-products and recycled products can be distinguished without necessitating the manual disaggregation of IO sectors. This is because the process table already contains disaggregated flows with the resolution to 
represent specific products. The framework is compiled by integrating a comprehensive Australian-specific LCI database with a monetary supply-and-use table (SUT) in order to draw information regarding the physical input recipe and the associated emissions of producing a single unit of waste or recycled product. Physical MFA data (that represent the quantity of economy-scale flows of waste or recycled products) replace monetary flows in the IOT in the downstream cut-off $\left(\mathbf{C}^{\mathrm{d}}\right)$ matrix (refer to S3.1.3) that connects the IOT with the LCI database, and the missing upstream inputs are filled in the upstream cut-off $\left(\mathbf{C}^{\mathrm{u}}\right)$ matrix (refer to S3.1.4) (Fig. 5).

\subsection{Application of MU-hLCA to recycled construction materials}

\subsubsection{Recycled concrete aggregate and by-products used in concrete}

In Australia, concrete waste is recycled as recycled aggregate (RA) and is most commonly utilised in unbound applications including road sub-base, pavement, drainage and landscaping (Net Balance 2012). Concrete waste recycling process involves crushing, sorting and screening that are processed on the construction site itself or transported to other processing sites to produce RA (Tam 2009; Tam et al. 2018). Recycled concrete aggregate (RCA) is RA that is used to replace natural (coarse) aggregate (NA) in new concrete. Of the $6 \mathrm{Mt}$ of concrete waste that is recycled in Australia (Net Balance 2012), only a small amount (0.5 Mt) is used in bound applications as RCA, such as in new low-strength, non-structural concretes (CCAA 2008; Tam et al. 2018). The potential of replacing NA with RCA in fly ash-based GPC has also been studied by Galvin and Lloyd (2011) and Limbachiya et al. (2012), who recommended that a 30\% RCA replacement rate is ideal to avoid adversely impacting the physical properties of fly ashbased GPC. By-products such as fly ash (FA) and ground granulated blast furnace slag (GGBFS) from coal and steel production that would otherwise be sent to the landfill can also be reused as ingredients for GPC, which is a low-carbon alternative to ordinary Portland cement (OPC) concrete.

Although there are numerous benefits of recycling $C \& D$ waste (for instance the reduction of waste disposal and thus the need for landfill space, and the conservation of natural resources), currently no RCA is used in high-grade structural applications in Australia (Wijayasundara et al. 2016) and only 1\% is used worldwide (Tošić et al. 2015). This is because the utilisation of RCA in structural applications is currently not supported by existing Australian technical and performance standards (Berndt et al. 2013; CSIRO 2002; Tam et al. 2013), and it is known to have lower quality and strength attributes compared to NA (Senaratne et al. 2017). Hence, there is potential for increasing the use of RCA in concrete applications, such as in the production of different concrete types and in various structural applications.

\subsubsection{Iron and steel scrap}

Metal waste, which is predominantly composed of steel, has a high recycling rate because of its profitability. In Australia, more than 50\% of metal scrap is exported (ACOR 2015; Corder et al. 2015). According to Hyder Consulting (2009), around 89\% (2.5 Mt) of steel waste is recycled and the rest $(0.3 \mathrm{Mt})$ is landfilled in Australia. A study by Golev and Corder (2016) showed that although the reported metal scrap recycling rates are high, 
i.e. in the range of $80-90 \%$, actual metal recycling rates are estimated to be below $70 \%$ when losses and end-of-life product dissipation are taken into account.

The recycling of steel involves the processes of collecting, sorting, shredding, and separating different types of scrap metals (Björkman and Samuelsson 2014). In the electric arc furnace (EAF) fabrication of steel products, iron and steel scrap are the primary inputs (ACOR 2015), along with pig iron, electricity as the main energy source, coke, fluxes, and cryogenic gases. The proportion of scrap utilisation in steel-making is estimated to be around $93 \%$ for EAF and around $5 \%$ in blast furnace-basic oxygen furnace (BF-BOF) production in Australia (Energetics 2012). The production of steel via the EAF route increased from 18\% in 2003 to 23\% in 2012 in Australia (Golev and Corder 2016) and currently accounts for approximately $30 \%$ of global steel output (Yellishetty et al. 2010). A detailed study by Golev and Corder (2016) estimated that currently in Australia, crude steel comprises $20-30 \%$ of recycled material content. Emissions can be reduced by recycling steel, given that it is a versatile material that can be recycled and reused efficiently and indefinitely.

\section{Method and data}

\subsection{Construction of MU-hLCA matrix}

The MU-hLCA method connects a top-down IOT matrix with a comprehensive bottom-up LCI process matrix through the $\mathbf{C}^{\mathrm{u}}$ and $\mathbf{C}^{\mathrm{d}}$ matrices (Fig. 5).

\subsubsection{Process matrix and process environmental extension matrix}

The process matrix and the process-based environmental extension matrix utilised in this study (referred to as the "process system" and indicated by the subscript ${ }_{p}$ ) is from the Australian Life Cycle Inventory database (AusLCI 2015), which captures 4463 processes and four selected environmental extensions, including direct emissions of methane $\left(\mathrm{CH}_{4}\right)$, nitrous oxide $\left(\mathrm{N}_{2} \mathrm{O}\right)$, carbon dioxide $\left(\mathrm{CO}_{2}\right)$, and carbon dioxide equivalents $\left(\mathrm{CO}_{2}\right.$-eq).

The preparation of the process coefficient matrix $\left(\mathbf{I}-\mathbf{A}_{\mathrm{p}}\right)$ for Eq. 3 comprises a procedure that normalises the LCI database and the associated environmental extension data to reflect the physical functional flows and the process emission intensity $\left(\mathbf{f}_{\mathrm{p}}\right)$ for the fabrication of one functional unit of product or process. The consumption of inputs is represented as negative values whilst the production of outputs are represented as positive values. Finally, the normalised functional units (represented by a series of $1 \mathrm{~s}$ ) are placed on the diagonal of the process coefficient matrix.

\subsubsection{Input-output matrix and associated GHGE extension matrix}

The IO matrix and IO environmental extension matrix used for this study (referred to as the "IO system" and indicated by the subscript ${ }_{\mathrm{IO}}$ ) is the same two-region SUT framework used in Teh et al. (2017), which in turn is based on data from the Australian Industrial Ecology Virtual Laboratory (IELab) (Lenzen et al. 2014, 2017). It comprises 341 industries, 345 products, 26 rest-of-the-world ( $\mathrm{RoW}$ ) sectors, and four environmental extensions representing direct emissions of $\mathrm{CH}_{4}, \mathrm{~N}_{2} \mathrm{O}, \mathrm{CO}_{2}$, and $\mathrm{CO}_{2}$-eq for the year 2009. The SUT framework is adopted because of its ability to capture industry and product detail that enables the allocation of co-products to an industry. 
The IO sectors listed below have been disaggregated and replaced with specific process data in previous studies (Teh et al. 2017; McIlvin 2015) to reflect detailed construction materials, which are represented as blue lines and dots in Fig. 5:

- Cement: Selected IO data in the "Cement" sector was replaced with process data for OPC (Teh et al. 2017).

- Concrete: The "Ready-mixed concrete and mortar" sector was disaggregated into six types of concrete with varying incorporated proportions of OPC, FA and GGBFS as well as FA-based and GGBFS-based GPC (Teh et al. 2017). The concrete types used in this study are "100\% OPC 50 MPa concrete" (referred to as OPC concrete) in S4.2.1 and "90\% FA/10\% GGBFS Geopolymer $50 \mathrm{MPa}$ concrete" (referred to as FAbased GPC) in S4.1 and S4.2.1.

- Steel: The "Other steel and iron manufacturing" sector was disaggregated into "BOF steel manufacturing" and "EAF steel manufacturing" sectors (McIlvin 2015).

The technology coefficient $\left(\mathbf{A}_{\mathrm{IO}}\right)$ matrix is first calculated by dividing each transaction $\left(\mathrm{x}_{i j}\right)$ in the $\mathbf{T}$ matrix by the total industry output $\left(\mathrm{X}_{j}\right)$, and then deducted from the identity (I) matrix to yield the "I- $\mathbf{A}_{\mathrm{IO}}$ matrix" for Eq. 3. The direct intensity multipliers $\left(\mathbf{f}_{\mathrm{IO}}\right)$ vector expressed in $\mathrm{kg}$ of GHGE per \$ (AUD) is obtained by dividing the IO environmental extension vector $\left(\mathrm{E}_{j}\right)$ by the total industry output $\left(\mathrm{X}_{j}\right)$.

\subsubsection{Downstream cut-off matrix}

The $\mathbf{C}^{\mathrm{d}}$ matrix captures the physical amount of products produced by the processes that are distributed to the IO system (Peters and Hertwich 2006; Suh 2006). The $\mathbf{C}^{\mathrm{d}}$ matrix is derived by "dividing the annual sales of functional flow-in physical units that are relevant to each functional flow-by the production of each total commodity." (Suh 2004, p. 459)

For instance, this study models the material flow of RCA replacing NA, which is labelled "Gravel" in the IO system, in the production of concrete. This is done by allocating the total annual physical amount of RCA, which is used by the "100\% OPC $50 \mathrm{MPa}$ concrete" column sector in the background IO system, to the "Recycling brick rubble and concrete, at plant/AU U" row in the process system, and then dividing it by the annual sales of the concrete sector. This calculation step produces the corresponding cell input $a_{h j}^{C^{\mathrm{d}}}$ (Eq. 1) and is expressed in $\mathrm{kg} / \$$, which represents the technology coefficient of RCA (Fig. 2). Subsequently, $a_{i j}^{\text {IO }}$ (Eq. 2), which is the sales coefficient of product row "Gravel" in the "100\% OPC 50 MPa concrete" industry sector column in the use table is adjusted (set to zero in this case) to avoid double counting (Fig. 2). Adjustments in the final demand vectors need to be made accordingly. However, since there is no final demand for RCA or gravel, no further corrections were necessary in this case.

$$
a_{h j}^{\mathbf{C}^{\mathrm{d}}}=\frac{x_{h j}^{\mathbf{C}^{\mathrm{d}}}}{X_{j}^{\mathrm{IO}}}
$$




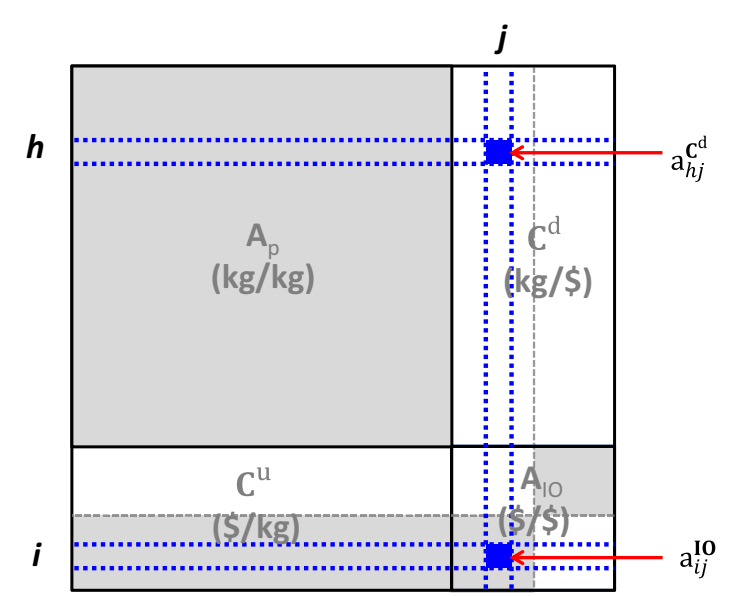

Fig. 2 Technology coefficient matrix elements in the $\mathbf{C}^{\mathrm{d}}$ and $\mathbf{A}_{\mathrm{IO}}$ matrix, in a case where product $i$ is replaced by product $h$ in $j$ industry sector (Eqs. 1 and 2)

$$
a_{i j}^{\mathbf{I O}}=\frac{\left(x_{i j}^{\mathbf{I O}}-x_{h j}^{\mathbf{C}^{\mathrm{d}}}\right)}{X_{j}^{\mathbf{I O}}}
$$

In this example, row $h$ is the product RCA, row $i$ is the product NA, and column $j$ is the concrete industry sector: $a_{h j}^{\mathrm{C}^{\mathrm{d}}}=$ technology coefficient matrix element $(a)$ of row $h$ and column $j$ (in the $\mathbf{C}^{\mathrm{d}}$ matrix; measured in $\mathrm{kg} / \$$ ); $a_{i j}^{\mathbf{I O}}=$ modified sales coefficient matrix element ( $a$ ) of row $i$ and column $j$ (in the IO system; measured in $\$ / \$$ ), in a case where a virgin material (from the IO system) is completely replaced by a recycled material (from the process system); $x_{h j}^{\mathbf{C}^{\mathrm{d}}}=$ physical amount of product $h$ used by sector $j$ (in the $\mathbf{C}^{\mathrm{d}}$ matrix; measured in $\mathrm{kg}$ ); $x_{i j}^{\mathrm{IO}}=$ monetary amount of product $i$ purchased by sector $j$ (in the IO system; measured in $\$$ ); $X_{j}^{\mathbf{I O}}=$ total industry output of sector $j$ (measured in $\$$ ).

The resolution of the detailed functional flows specified in the process system is useful for recycled products (e.g. RCA, iron and steel scrap), by-products (e.g. FA and GGBFS), and specific chemicals [e.g. sodium hydroxide $(\mathrm{NaOH})$ and sodium silicate $\left.\left(\mathrm{Na}_{2} \mathrm{SiO}_{3}\right)\right]$ that are not individually reflected in the aggregated IO system. For this study, the $\mathbf{C}^{\mathrm{d}}$ matrix is populated with physical economy-wide material flow data of the following, which are represented as red dots in Fig. 5:

- FA, GGBFS, $\mathrm{NaOH}$, and $\mathrm{Na}_{2} \mathrm{SiO}_{3}$ for the "90\% FA/10\% GGBFS Geopolymer $50 \mathrm{MPa}$ concrete" sector for S4.1;

- RCA for the "100\% OPC $50 \mathrm{MPa}$ concrete" sector for S4.2.1;

- RCA, FA, GGBFS, $\mathrm{NaOH}$ and $\mathrm{Na}_{2} \mathrm{SiO}_{3}$ for the "90\% FA/10\% GGBFS Geopolymer $50 \mathrm{MPa}$ concrete" sector for S4.2.1; and

- Iron and steel scrap for the "BOF steel manufacturing" and "EAF steel manufacturing" sectors for S4.2.2. 


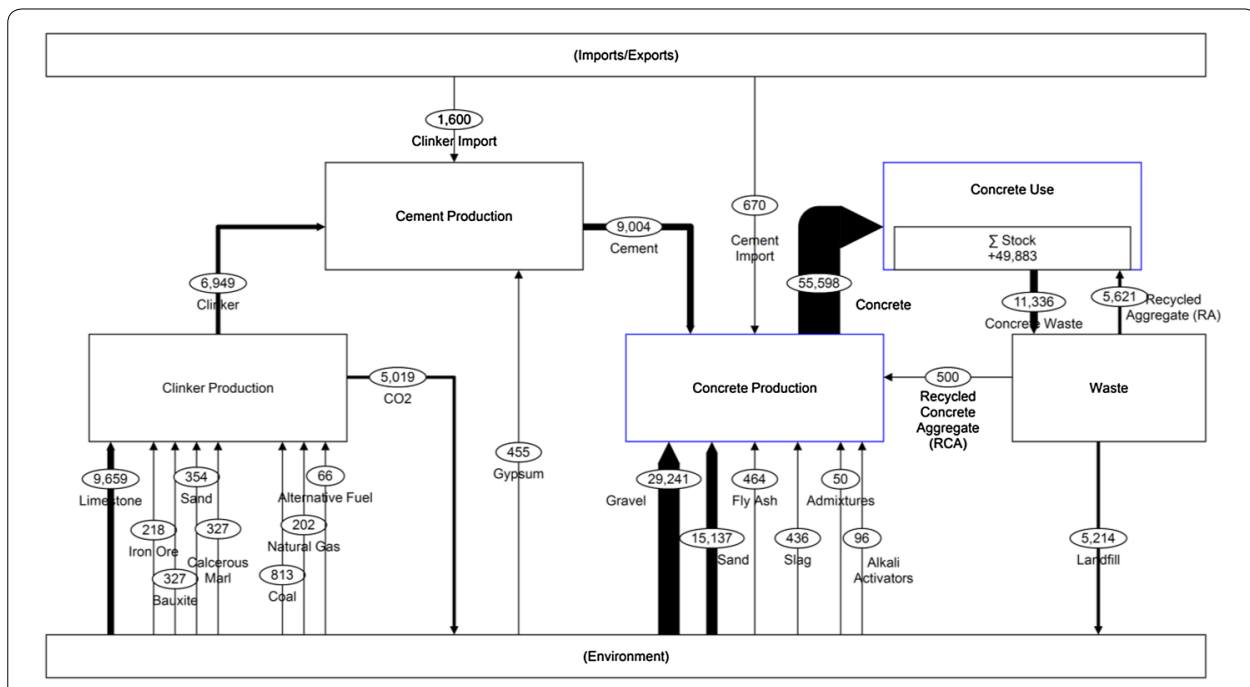

Fig. 3 MFA of concrete production in Australia for 2008-2009 in kt/year

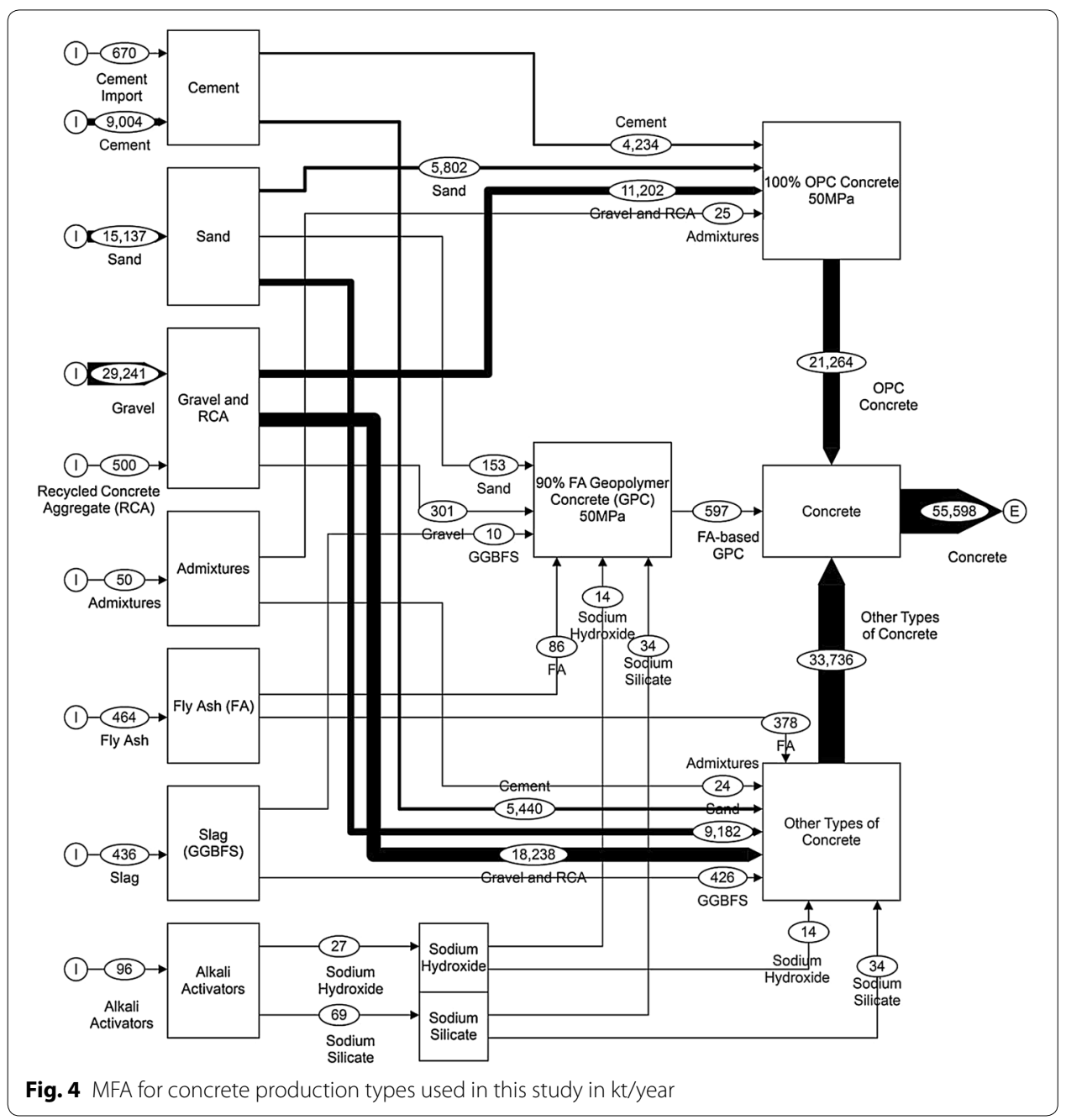




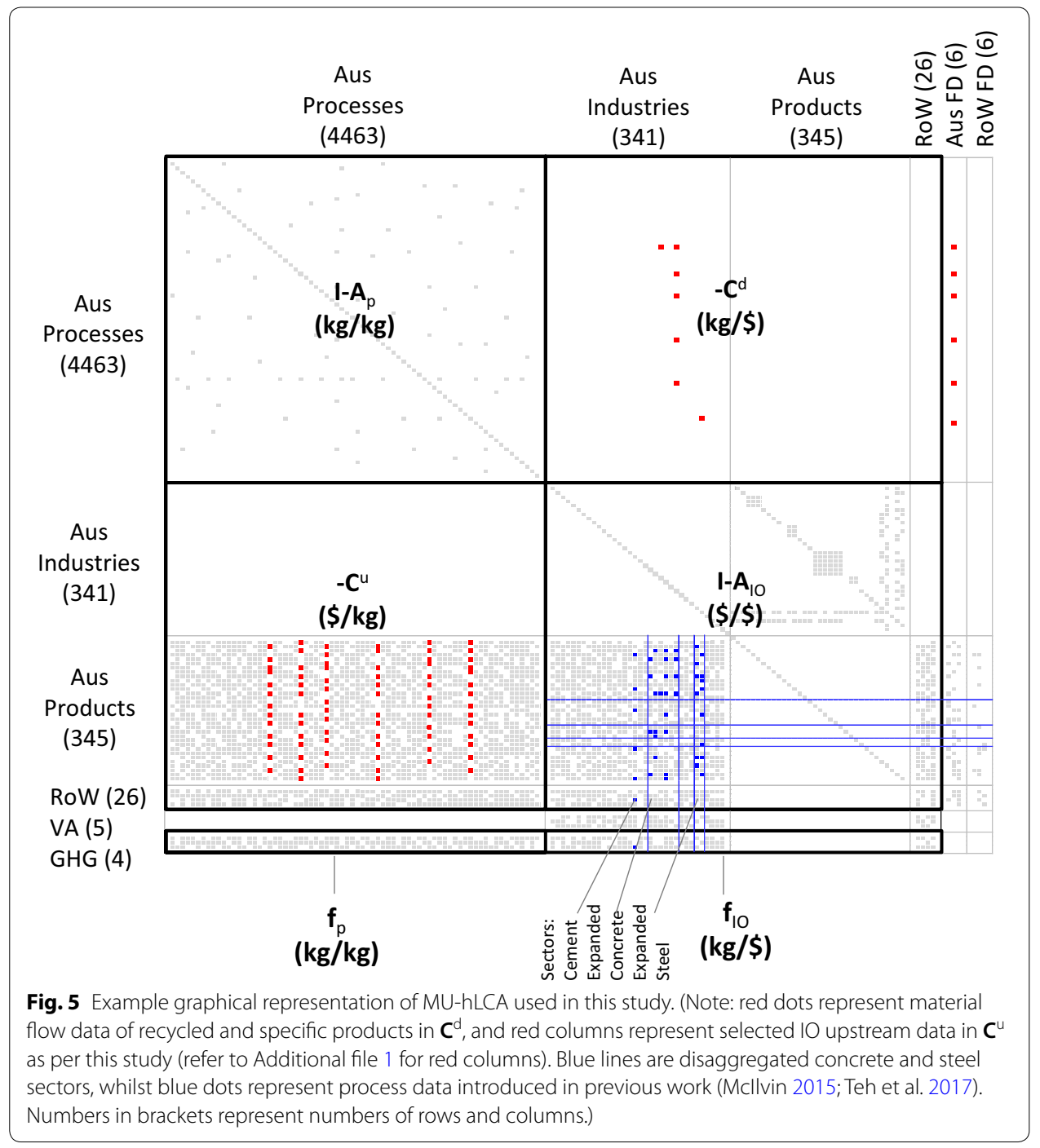

The concrete material flow data for $\mathbf{C}^{\mathrm{d}}$ matrix is shown in Figs. 3 and 4 using STAN (Brunner and Rechberger 2004; Cencic and Rechberger 2008). Steel material flow data is based on Energetics (2012, Fig. 5). An example of calculating $\mathbf{C}^{\mathrm{d}}$ with a matrix of eight processes, three industries, and five product sectors is available in the form of an Excel sheet and MATLAB script in supplementary information (SI) provided in Teh and Wiedmann (2017).

\subsubsection{Upstream cut-off matrix}

The $\mathbf{C}^{\mathrm{u}}$ matrix complements the process system by adding any absent higher upstream monetary input data from IO flows to the process system (Suh 2004). The full procedure to construct the $\mathbf{C}^{\mathrm{u}}$ matrix is employed from Wiedmann et al. (2011, Supplementary Information) to completely fill the $\mathbf{C}^{\mathrm{u}}$ matrix in this study.

For this study, selected processes in the $\mathbf{C}^{\mathrm{u}}$ matrix are replaced with IO sales coefficients $\left(\mathbf{A}_{\mathrm{IO}}\right)$ of relevant Australian industry sectors from the use table of the IO system, which are then adjusted via multiplication with the Australian unit price of a functional 
unit of the process inventory employed. This represents the total cost of input process required to produce $1 \mathrm{~kg}$ functional unit of a process. To avoid double counting, all upstream inputs that are already accounted for in the process inventory employed are removed from the column vector. The unit price (AUD/kg) of FA, GGBFS, $\mathrm{NaOH}$, and $\mathrm{Na}_{2} \mathrm{SiO}_{3}$ from Teh et al. (2017, Supplementary Information, Table A.3) are applied in this study. The prices of RCA and iron and steel scrap are obtained from Tam (2008) and ABARES (2010).

If technology coefficients data are absent in the IO system for a particular product, price-weighted coefficients need to be assembled from monetary data. For RCA, the Australian concrete recycling cost data is sourced from Tam (2008, Table 2), which is then assigned to a corresponding IO product sector. The technology coefficients vector is calculated by dividing each recycling cost in proportion to the total annual cost of concrete recycling. The price-weighted coefficient is then computed by multiplying the cost of $1 \mathrm{~kg}$ of RCA (0.02 AUD/kg from Tam (2008)) with the technology coefficients vector. Lastly, inputs that are already accounted for in the "Recycling brick rubble and concrete, at plant/AU U" AusLCI process inventory (Grant 2015) are deleted to avoid double counting. Selected processes for this study in the $\mathbf{C}^{\mathrm{u}}$ matrix are represented as red columns in Fig. 5 and described in Additional file 1.

\subsection{Methods}

Total impact multipliers $\left(\mathbf{m}_{\mathrm{MUH}}\right)$ from MU-hLCA are calculated according to Eq. 3 (Hawkins et al. 2007; Suh 2004, 2011), whereby the first row vector $\left(\mathbf{f}_{\mathrm{MUH}}\right)$ represents the direct intensity multipliers of the process and IO system, whilst the second matrix $\left(\mathbf{I}-\mathbf{A}_{\mathrm{MUH}}\right)^{-1}$ represents the Leontief inverse (Leontief 1970) of the process, $\mathbf{C}^{\mathrm{u}}, \mathbf{C}^{\mathrm{d}}$ and IO system. The total impact multipliers $\left(\mathbf{m}_{\mathrm{MUH}}\right)$ are referred to as CFI in the results and discussion section. For an example of $\mathbf{m}_{\mathrm{MUH}}$ calculation, see SI provided in Teh and Wiedmann (2017).

$$
\mathbf{m}_{\mathrm{MUH}}=\mathbf{f}_{\mathrm{MUH}}\left(\mathbf{I}-\mathbf{A}_{\mathrm{MUH}}\right)^{-1}=\left[\mathbf{f}_{\mathrm{p}} \mathbf{f}_{\mathrm{IO}}\right]\left[\begin{array}{cc}
\mathbf{I}-\mathbf{A}_{\mathrm{p}} & -\mathbf{C}^{\mathrm{d}} \\
-\mathbf{C}^{\mathrm{u}} & \mathbf{I}-\mathbf{A}_{\mathrm{IO}}
\end{array}\right]^{-1}
$$

where $\mathbf{m}_{\mathrm{MUH}}=$ row vector of CFIs, consisting of $\left[\mathbf{m}_{\mathrm{p}} \mathbf{m}_{\mathrm{IO}}\right]$ (where $\mathbf{m}_{\mathrm{p}}$ is measured in $\mathrm{kg} \mathrm{CO}$-eq/ $/ \mathrm{kg}$; dimension: $1 \times 4463)$ and $\mathbf{m}_{\mathrm{IO}}$ is measured in $\mathrm{kg} \mathrm{CO}_{2}$-eq/\$; dimension: $1 \times(341+345+26)) ; \mathbf{f}_{\mathrm{p}}=$ process system environmental extension vector for GHGE (measured in $\mathrm{kg} \mathrm{CO}_{2}$-eq $/ \mathrm{kg}$; dimension: $\left.1 \times 4463\right) ; \mathbf{f}_{\mathrm{IO}}=$ direct intensity multiplier vector of the IO system for GHGE (measured in $\mathrm{kg} \mathrm{CO}_{2}$-eq/\$; dimension: $1 \times(341+345+26)$ ); $\mathbf{I}-\mathbf{A}_{\mathrm{p}}=$ process coefficient matrix $\left(\mathbf{A}_{\mathrm{p}}\right)$ deducted from the normalised functional unit (measured in $\mathrm{kg} / \mathrm{kg}$; dimension: $4463 \times 4463$ ); $-\mathbf{C}^{\mathrm{d}}=$ downstream cut-off matrix (measured in $\mathrm{kg} / \$$; dimension: $4463 \times(341+345+26))$, where seven matrix elements are introduced in $\mathbf{C}^{\mathrm{d}}$ in this study, shown in Fig. $5 ;-\mathbf{C}^{\mathrm{u}}=$ upstream cut-off matrix (measured in $\$ / \mathrm{kg}$; dimension $(341+345+26) \times 4463)$, where the whole $\mathbf{C}^{\mathrm{u}}$ matrix is filled in this study, shown in Fig. 5; $\mathbf{I}-\mathbf{A}_{\mathrm{IO}}=\mathrm{IO}$ technology coefficient matrix $\left(\mathbf{A}_{\mathrm{IO}}\right)$ deducted from the identity matrix (I) (measured in \$/ \$; dimension: $(341+345+26) \times(341+345+26))$.

To recognise impacts from LCI processes, IO industries, and IO products, a method to decompose total impact multipliers tailored for MU-hLCA was developed based on a 
method by Wiedmann (2017). "Decomposition of integrated hybrid life cycle inventories by final-stage inputs" is applied as per Eq. 4, which distinguishes the contributions of direct and indirect emissions from industries, products and processes (Teh and Wiedmann 2017). This method shows the life cycle impacts originating from specific products used in the $\mathbf{C}^{\mathrm{d}}$ matrix (e.g. $\mathrm{RCA}, \mathrm{FA}, \mathrm{NaOH}$ ).

$$
\mathbf{M}^{i f s i}=\hat{\mathbf{f}}_{\mathrm{MUH}}+\hat{\mathbf{m}}_{\mathrm{MUH}} \cdot \mathbf{A}_{\mathrm{MUH}}
$$

where $\hat{\mathbf{f}}_{\mathrm{MUH}}=$ diagonalised direct emissions of the process system $\left(\mathbf{f}_{\mathrm{p}}\right)$ (measured in $\mathrm{kg}$ $\mathrm{CO}_{2}$-eq $/ \mathrm{kg}$ ) and the IO system $\left(\mathbf{f}_{\mathrm{IO}}\right)$ (measured in $\mathrm{kg} \mathrm{CO}_{2}$-eq/\$) shown in Eq. 5;

$$
\hat{\mathbf{f}}_{\mathrm{MUH}}=\left[\begin{array}{cc}
\hat{\mathbf{f}}_{\mathrm{p}} & 0 \\
0 & \hat{\mathbf{f}}_{\mathrm{IO}}
\end{array}\right]
$$

$\hat{\mathbf{m}}_{\mathrm{MUH}}=$ diagonalised total impact multipliers of the process system $\left(\mathbf{m}_{\mathrm{p}}\right)$ (measured in $\mathrm{kg} \mathrm{CO}$-eq $/ \mathrm{kg}$ ) and the $\mathrm{IO}$ system $\left(\mathbf{m}_{\mathrm{IO}}\right)$ (measured in $\mathrm{kg} \mathrm{CO}_{2}$-eq $/$ ) shown in Eq. 6; equivalent to diagonalised $\mathbf{m}_{\mathrm{MUH}}$ from Eq. 3;

$$
\hat{\mathbf{m}}_{\mathrm{MUH}}=\left[\begin{array}{cc}
\hat{\mathbf{m}}_{\mathrm{p}} & 0 \\
0 & \hat{\mathbf{m}}_{\mathrm{IO}}
\end{array}\right]
$$

$\mathbf{A}_{\mathrm{MUH}}=$ mixed-unit coefficient matrix of the MU-hLCA, calculated by deducting (I $\mathbf{A}_{\mathrm{MUH}}$ ) from the I matrix (measured in $\mathrm{kg} / \mathrm{kg}, \mathrm{kg} / \$ ; \$ / \mathrm{kg}, \$ / \$$ ), shown in Eq. 7 (Peters and Hertwich 2006).

$$
\mathbf{A}_{\mathrm{MUH}}=\mathbf{I}-\left(\mathbf{I}-\mathbf{A}_{\mathrm{MUH}}\right)=\mathbf{I}-\left[\begin{array}{cc}
\mathbf{I}-\mathbf{A}_{\mathrm{p}} & -\mathbf{C}^{\mathrm{d}} \\
-\mathbf{C}^{\mathrm{u}} & \mathbf{I}-\mathbf{A}_{\mathrm{IO}}
\end{array}\right]=\left[\begin{array}{cc}
\mathbf{A}_{\mathrm{p}} & \mathbf{C}^{\mathrm{d}} \\
\mathbf{C}^{\mathbf{u}} & \mathbf{A}_{\mathrm{IO}}
\end{array}\right]
$$

\section{Results and discussion}

The results calculated via Eq. 3 are expressed as CFI per unit of construction material, and denote the cradle-to-gate life cycle amount of GHGE represented as $\mathrm{CO}_{2}$-eq (sum of $\mathrm{CO}_{2}, \mathrm{CH}_{4}$ and $\mathrm{N}_{2} \mathrm{O}$ ). The decomposition of CFI identifies the major sources of GHGE originating from industries, products and processes along the supply chain of construction materials. S4.1 presents the CFI results of MU-hLCA compared with process-based LCA (Davidovits 2015; Turner and Collins 2013) and IO-hLCA (Teh et al. 2017) using GPC as a case study. S4.2.1 and S4.2.2 are application studies of MU-hLCA for recycled construction materials used in concrete and steel, respectively. The same concrete mix-designs for $1 \mathrm{~m}^{3}$ of concrete used in Teh et al. (2017, Supplementary Information, Table A.2) are applied in the "100\% OPC 50 MPa concrete" industry sector in S4.2.1 and in the "90\% FA/10\% GGBFS Geopolymer 50 MPa concrete" industry sector in S4.1 and S4.2.1. For S4.2.2, the same process inputs for steel used by McIlvin (2015, Table 13 and 20) based on Ecoinvent data are applied in the "BOF steel manufacturing" and the "EAF steel manufacturing" industry sectors, which use 5 and $74 \%$ of recycled iron and steel scrap, respectively. Numerical results for all figures are provided in Additional file 1.

\subsection{Method comparison}

The process-based LCA methodology presents a CFI of $170 \mathrm{kgCO}{ }_{2}$-eq $/ \mathrm{m}^{3}$ (Davidovits 2015; Turner and Collins 2013). When other inputs not covered by LCA are included from the IO sectors, CFI more than doubles to $345 \mathrm{kgCO}_{2}-\mathrm{eq} / \mathrm{m}^{3}$ for IO-hLCA (Teh 


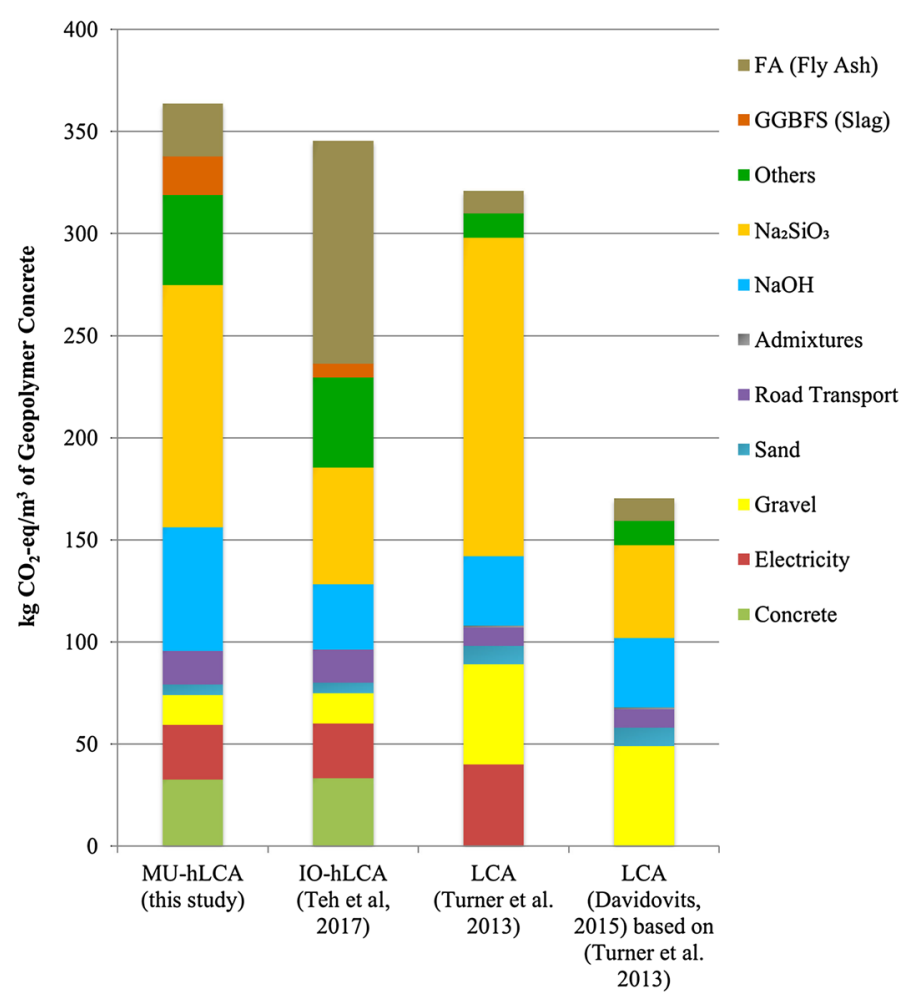

Fig. 6 Contributions of main GHGEs for FA-based geopolymer concrete production by MU-hLCA, IO-hLCA, and LCA methodologies

et al. 2017) and increases to $364 \mathrm{~kg} \mathrm{CO}$-eq $/ \mathrm{m}^{3}$ for MU-hLCA (Fig. 6). The major disparity can be seen in the allocation of embodied emissions to FA and GGBFS. In the LCA study (Turner and Collins 2013), the contribution of FA was $11 \mathrm{kgCO}_{2}-\mathrm{eq} / \mathrm{m}^{3}$, because only post-production emissions of FA including "capture, milling, grinding, drying and transport" were considered, and no GGBFS was used in the LCA study.

In this MU-hLCA study, a higher result of $19 \mathrm{kgCO}_{2}$-eq $/ \mathrm{m}^{3}$ is calculated for GGBFS compared to IO-hLCA. This is because by-products are allocated based on physical units, and they represent Australian-specific production and emission patterns, which have been adopted from AusLCI. In the instance of GGBFS, the main inputs accounted for are mixing, energy, plant use and transportation. This is a more accurate analysis because it takes into account the international and local transportation of GGBFS, of which are $80 \%$ imported from Japan (ABS 2013). In the previous IO-hLCA study (Teh et al. 2017), GGBFS was calculated to contribute $7 \mathrm{kgCO}_{2}$-eq $/ \mathrm{m}^{3}$, because it was aggregated into the 26 -sector RoW table and thus assumed to be entirely produced locally, ignoring any impacts associated with importing from abroad.

For FA, a lower result of $26 \mathrm{kgCO}_{2}-\mathrm{eq} / \mathrm{m}^{3}$ is calculated in this study compared to IOhLCA. In AusLCI, FA is considered as waste and only local transportation is accounted for. For a more accurate analysis, missing upstream emissions of electricity generation are taken into account by allocating the "Electricity generation" IO technology coefficient sector to the FA process (detailed procedure described in S3.1.4 and Additional file 1). The contribution of upstream emissions from electricity generation and 


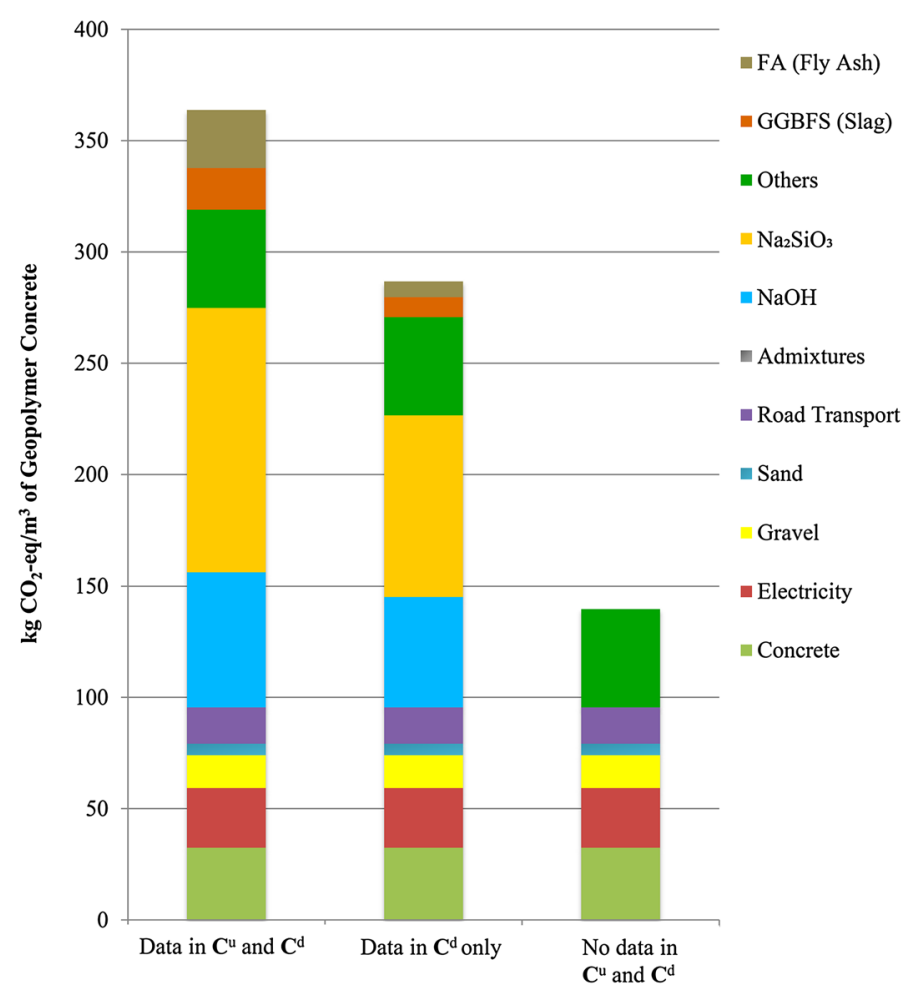

Fig. 7 Contributions of upstream and downstream cut-off matrix for FA-based geopolymer concrete production using MU-hLCA

other upstream supply chains is given in Fig. 7. The emissions of FA increased from 7 $\mathrm{kgCO}_{2}$-eq $/ \mathrm{m}^{3}$ (when only the $\mathrm{C}^{\mathrm{d}}$ matrix is populated with data) to $26 \mathrm{kgCO}_{2}$-eq $/ \mathrm{m}^{3}$ (when both the $\mathbf{C}^{\mathrm{u}}$ and $\mathbf{C}^{\mathrm{d}}$ matrices are populated with data). In contrast, FA contribution was $109 \mathrm{kgCO}_{2}$-eq $/ \mathrm{m}^{3}$ due to its high average price, with a sensitivity range of -32 to $+10 \%$ based on variances in FA market prices in the previous IO-hLCA study (Teh et al. 2017). Via economic allocation, emissions were assigned according to monetary values between electricity generation and FA based on estimated prices. FA was introduced in the IOT by creating new columns and rows because it was not represented in the IOT. Although upstream impacts were accounted for, the IOT sectors were aggregated and the results were sensitive to price variability.

Contributions of $\mathrm{Na}_{2} \mathrm{SiO}_{3}$ and $\mathrm{NaOH}$ calculated using MU-hLCA (119 and 61 $\mathrm{kgCO}{ }_{2}$-eq $/ \mathrm{m}^{3}$ ) are higher compared to using IO-hLCA (57 and $32 \mathrm{kgCO}_{2}$-eq $/ \mathrm{m}^{3}$ ) and LCA ( 45 and $34 \mathrm{kgCO}_{2}$-eq/ $\mathrm{m}^{3}$ ) (shown in Fig. 6). It is noted that consistently across all methods, $\mathrm{Na}_{2} \mathrm{SiO}_{3}$ and $\mathrm{NaOH}$ are identified as the main contributors of GHGE in the production of GPC. Other studies also confirm that either $\mathrm{Na}_{2} \mathrm{SiO}_{3}$ or $\mathrm{NaOH}$ is the biggest emitter in GPC production (Davidovits 2015; Habert et al. 2011; McLellan et al. 2011). This study has incorporated all modifications involving the conversion of $\mathrm{Na}_{2} \mathrm{SiO}_{3}$ and $\mathrm{NaOH}$ from dry weight into $45 \%$ wt solution form for feedstock.

The higher value of MU-hLCA is due to the use of Australian-specific data (e.g. local energy mix) and the selection of specific chemical production methods from AusLCI. For $\mathrm{Na}_{2} \mathrm{SiO}_{3}$ production in Australia, the furnace process is used to melt sodium 
carbonate and silica sand to produce solid $\mathrm{Na}_{2} \mathrm{SiO}_{3}$, which is then dissolved in water to produce liquor $\mathrm{Na}_{2} \mathrm{SiO}_{3}$ (Turner and Collins 2013). Production of $\mathrm{NaOH}$ is done via the chlor-alkali process, whereby electrolysis converts sodium chloride brine solution to chlorine and $\mathrm{NaOH}$ (Turner and Collins 2013). The membrane cell production method is employed by primary $\mathrm{NaOH}$ manufacturing companies in Australia (CoogeeChemicals 2016; Orica 2016). Habert and Ouellet-Plamondon (2016) discussed that the energy mix employed in the $\mathrm{NaOH}$ production influences the environmental impact data more than the type of production (e.g. membrane cell). Specific methods for the production of "Sodium silicate, furnace liquor, 37\% in $\mathrm{H}_{2} \mathrm{O}$, at plant/RER U/AusSD U" and "Sodium hydroxide, $50 \%$ in $\mathrm{H}_{2} \mathrm{O}$, membrane cell, at plant/RER U/AusSD U" are employed from AusLCI in the process system. The previous IO-hLCA study (Teh et al. 2017) has a few gaps, namely that chemical types were aggregated in the "Other basic chemical manufacturing" industry sector, specific diluted chemical solutions could not be distinguished and their conversion to monetary units was problematic. Missing upstream inputs from "Other basic chemical manufacturing" and other upstream supply chains to $\mathrm{Na}_{2} \mathrm{SiO}_{3}$ and $\mathrm{NaOH}$ in the $\mathrm{C}^{\mathrm{u}}$ matrix contributed to an increase of 38 and $11 \mathrm{kgCO}_{2}-\mathrm{eq} / \mathrm{m}^{3}$, respectively (Fig. 7). It should be noted that the $\mathrm{Na}_{2} \mathrm{SiO}_{3}$ and $\mathrm{NaOH}$ processes in AusLCI are derived from the "shadow database", meaning that whilst some significant processes such as those relating to energy and transport are Australian data, the remaining inputs are from the international Ecoinvent database. Hence, there is room for data improvement to achieve more accurate results.

In conclusion, the hLCA methodologies led to a higher GHGE of 100-114\% compared to the LCA approach due to their system boundary completeness. Although the results of the hLCA methods vary only slightly $\left(18 \mathrm{kgCO}_{2}\right.$-eq $\left./ \mathrm{m}^{3}\right)$, MU-hLCA yields a more accurate outcome due to (1) the high resolution and country-specific process and IO data available, (2) economy-wide material flow data, (3) the utilisation of physical units to represent by-products and specific chemical products, and (4) an economy-wide system boundary. The drawbacks of IO-hLCA, including the price variability issue, proportionality and homogeneity assumptions, and aggregated sectors, could be addressed with MU-hLCA.

\subsection{Application for recycled materials}

\subsubsection{Recycled concrete aggregate in OPC and GPC}

The goal of this study is to assess the hypothetical maximum emission reduction achievable using MU-hLCA if 100\% of NA (gravel) is replaced with RCA for both GPC and OPC concretes. In this study, concrete types using NA is referred to as "NA concrete," and concrete types using RCA as a replacement for NA is referred to as "RCA concrete". The actual amount of RCA used in Australian concrete is guided by the H155:2002 guideline (CSIRO 2002).

An environmental impact study of cradle-to-gate embodied emissions of RCA compared with NA concrete using hLCA has not yet been done. LCA studies have reported varying CFI of $320-343 \mathrm{kgCO}_{2}$-eq $/ \mathrm{m}^{3}$ for $100 \%$ RCA concrete (Marinković et al. 2017) and $271 \mathrm{kgCO}_{2}$-eq $/ \mathrm{m}^{3}$ for $30 \%$ RCA concrete (Kleijer et al. 2017). From this study, the CFI for $100 \%$ RCA OPC concrete in the Australian context is higher $\left(516 \mathrm{kgCO}_{2}\right.$-eq/ $\mathrm{m}^{3}$ ) as it includes emissions from upstream processes (Fig. 8). However, side-by-side 


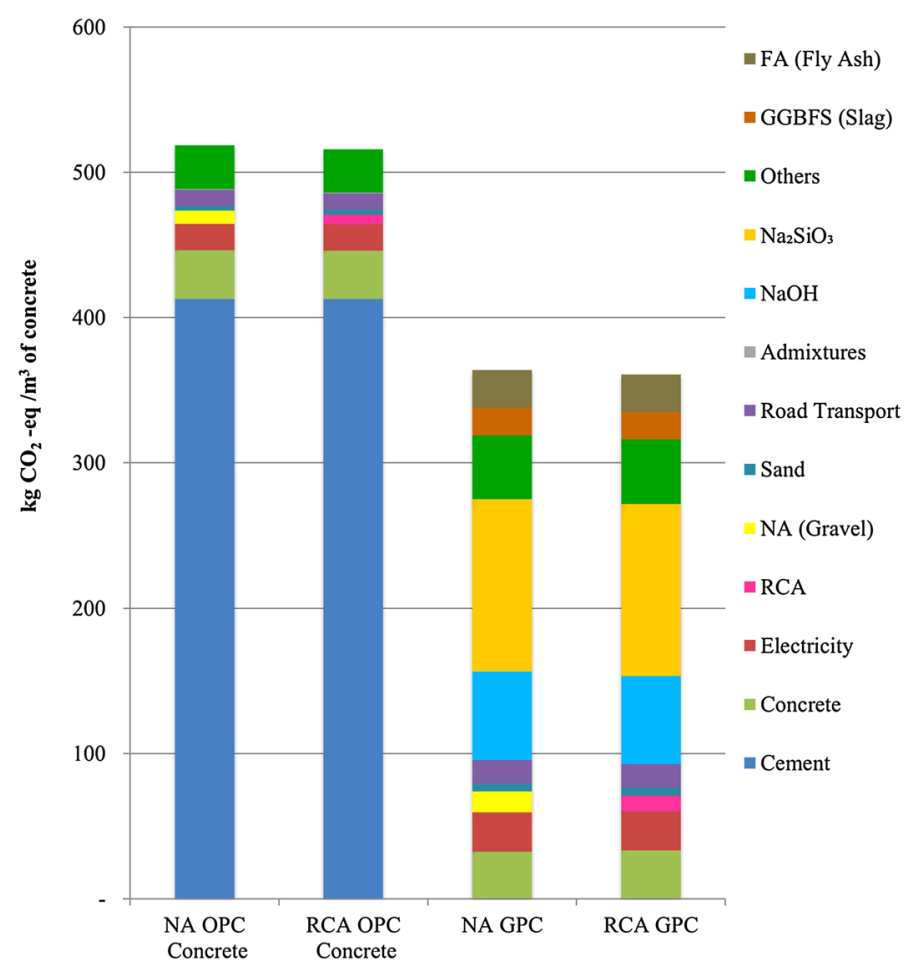

Fig. 8 CFls of geopolymer and OPC concrete, with either natural aggregate or 100\% recycled concrete aggregate

comparisons with LCA studies are difficult because there are too many different variables to be considered, such as country of study, mix proportions used for concrete, concrete strength class, RCA replacement rate, and transportation distance. The only hLCA study, of which the authors are aware, by Wijayasundara et al. (2017a) evaluated the embodied energy of RCA compared with NA concrete using IO-hLCA, and concluded that the difference is between -1 and $+2 \%$.

The $100 \%$ replacement of RCA for NA for both GPC and OPC concretes yields a GHGE reduction of $1 \%$. The differences are only due to NA production, given that the compared concrete types are the same, i.e. they use equal amounts of cement. Moreover, the contribution of NA is small to begin with ( $2 \%$ in OPC and $4 \%$ in GPC) compared to that of other processes in the life cycle emissions of concrete production. Previous LCA studies evaluating the environmental impacts of RCA concrete compared to NA concrete have produced similar or marginally higher results. An LCA study by Kleijer et al. (2017), which compared product-specific concretes of the same strength, concluded that RCA concrete yields a 2\% GHGE reduction. Braunschweig et al. (2011) and Knoeri et al. (2013) found that RCA concrete, including higher cement content, has produced similar GHGE with NA concrete using LCA. Knoeri et al. (2013) also considered the avoided impacts of C\&D waste disposal and steel recycling that led to a reduction of other environmental impacts, favouring the use of RCA.

A few LCA studies established that RCA transportation types and distances influence the environmental impact of RCA concrete. Marinković et al. (2010) concluded that environmental impact of $100 \%$ RCA concrete (with some additional cement) and 
NA concrete are the same if the transport distance of RCA are less than that of NA, but impacts of RCA concrete are larger when their transport distances are the same. An LCA study by Shan et al. (2017) recommended the use of local (Singaporean) RCA due to the higher environmental impact from the country's reliance on imported material, including NA. For this study, AusLCI physical data for RCA assumes that no transportation to the recycling plant is included because the end-of-waste phase is considered to be at the concrete recycling plant. For NA, the IO system uses an average distance calculation to account for local road transportation.

The versatility of MU-hLCA is demonstrated in this study by modelling RCA flows in physical units. Although GHGE reduction in RCA concrete is relatively small, using RCA has other benefits including reducing both waste being landfilled and the depletion of natural resources. A maximum potential GHGE reduction of $30 \%$ is achieved with RCA GPC compared to NA OPC concrete, as cement production is the largest contributor to environmental impact in OPC concrete. Apart from the environmental indicator, Wijayasundara et al. (2017b) and Tošić et al. (2015) conducted combined assessments to include other criteria such as social, financial and technical aspects for a more complete comparison.

\subsubsection{Iron and steel scrap in EAF steel}

Embodied emissions of iron and steel scrap used in BOF and EAF steel are modelled using MU-hLCA to assess the possible reductions in GHGE. Based on this, the CFI produced is $1.51 \mathrm{kgCO}_{2}$-eq per $\mathrm{kg}$ of BOF steel (Fig. 9). The largest source of GHGE is from the iron and steel manufacturing process, which accounts for $64 \%$ of total emissions. For EAF steel, the CFI produced is $0.87 \mathrm{kgCO}_{2}$-eq $/ \mathrm{kg}$ (Fig. 9). Electricity generation (predominantly based on coal power in Australia) is the largest emitter in the EAF route, contributing to $35 \%$ of emissions. It is noted that this represents a cradle-to-gate analysis of producing a unit $\mathrm{kg}$ of crude steel, and therefore does not account for the processes thereafter to produce various finished steel products.

In comparison, $\mathrm{CFI}$ in the range of $1.46-1.65 \mathrm{kgCO}_{2}$-eq $/ \mathrm{kg}$ was verified by Environmental Product Declarations (EPDs) for Australian-specific steel products manufactured by BlueScope (with $25 \%$ total recycled content) via the integrated steel-making method (BF-BOF route) (Australasian EPD 2015a, b, c). These values are in line with the results produced by this study, which does not take into account the last stage of steel processing. BlueScope reported that an increase of end-of-life recycling rate from the current 89 to $100 \%$ can achieve a $12 \%$ reduction in global warming potential (GWP), and emphasised the significance of reuse and recycling (Australasian EPD 2015a, b, c). WSA (2015) reported a GHGE of 1.8-1.9 $\mathrm{kg} \mathrm{CO}_{2}$ per $\mathrm{kg}$ of crude steel cast (for 2012-2014), that reflects the sustainability performance of more than $50 \%$ of global steel production. An LCA study by Burchart-Korol (2013) provided a mass allocation breakdown of GHGE for crude steel production, and reported emissions of $1.7 \mathrm{kgCO}_{2}$-eq/ $\mathrm{kg}$ for BOF steel and $0.76 \mathrm{kgCO}_{2}$-eq $/ \mathrm{kg}$ for EAF steel.

The environmental benefit of scrap usage is evident in the 43\% GHGE reduction via the EAF route compared with that of the BOF route (Fig. 9). According to WSA (2015), steel scrap recycling can conserve approximately $1400 \mathrm{~kg}$ of iron ore, $740 \mathrm{~kg}$ of coal, and $120 \mathrm{~kg}$ of limestone for every tonne of steel scrap used. In terms of energy, Yellishetty 


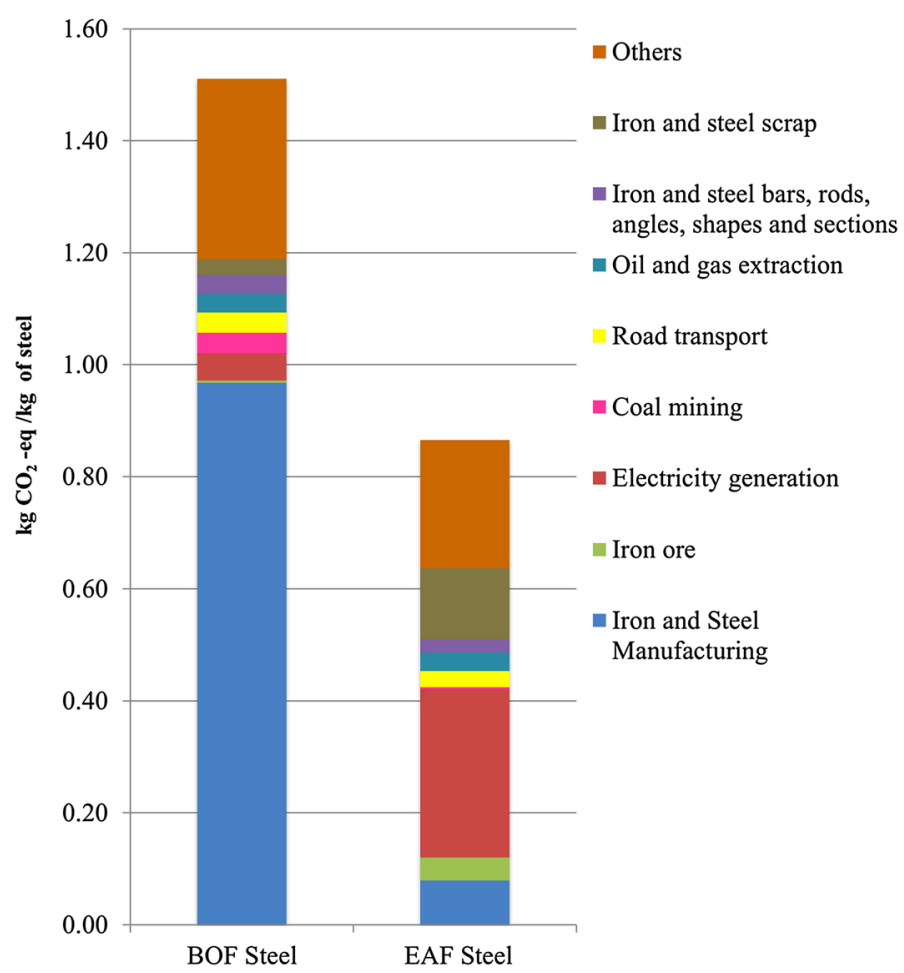

Fig. 9 CFIs of BOF and EAF steel, with the use of iron and steel scrap

et al. (2011) described the use of iron and scrap steel as beneficial from both economic and environmental perspectives because the products have already been refined and require minimal energy for additional processing.

The proportion of EAF steel currently stands at $22.8 \%$ in Australia and has the potential to increase, considering that approximately $1.7 \mathrm{Mt}$ of steel scrap is currently exported from Australia for external processing (Energetics 2012). However, the EAF route is dependent on the availability of iron and steel scrap, which can be limited due to the majority of steel remaining in use for long periods of time and some steel products are reused directly as new products without recycling or re-melting (Yellishetty et al. 2011). It should be noted that the two types of steel are not fully substitutable yet due to their difference in physical properties (Warrian 2016). However, the intention of this application study is to show that it is possible to assess the potential emission reduction using the MU-hLCA method when a recycled component is used.

\section{Assumptions and limitations}

Factors that influence the accuracy of the results:

- The MU-hLCA method is useful for modelling recycled and by-products when the LCI (process system) contains the recycling unit process information (including GHGE in this case), and this recycling information is either aggregated or not represented in the IO system. 
- Due to the lack of Australian steel industry data, the bottom-up process data replaced in the disaggregated steel sectors in the IO system is based on Ecoinvent data employed in a study by McIlvin (2015).

- AusLCI contains verified Australian unit processes, but where data is limited, it is populated with the shadow database modified from Ecoinvent data. Whilst some energy and transport-related processes are replaced with Australian data, better analysis can be conducted when more Australian-specific data are available.

- This study only assesses GHGE $\left(\mathrm{CO}_{2}\right.$-eq) as the single indicator. Other indicators are neglected in this study, but it is important to note that other impacts of $C \& D$ recycling such as the release of other waste and the use of energy, as well as financial, social and technical implications are also important.

- The MU-hLCA method is the most advanced form of hLCA methodology, but is also known to be laborious, as well as data and time intensive. To overcome this, Crawford et al. (2017) proposed the automation of integrating IO and process data.

\section{Conclusion}

Recycling studies are usually assessed using LCA and are not considered in the context of the wider economy. There are inherent problems in representing waste and recycled material flows in MIOT because they are either aggregated or not included, and the market value of waste can be little to none.

In this study, the Australian economy-wide potential use of recycled construction materials is modelled via the MU-hLCA method, using a combination of LCI, IO and material flow data. By combining physical units of industrial systems representing construction and recycled materials with monetary units of the IO economic sectors, the model enables a more precise computation of embodied carbon and improves the accuracy of tracking material flows.

Using GPC as a case study, CFI results derived from MU-hLCA are 5 and 114\% higher than IO-hLCA and LCA. MU-hLCA produces more accurate results as it utilises an economy-wide system boundary and Australian process-specific physical flows. Disadvantages of IO-hLCA relating to price variability, assumptions of proportionality, and homogeneity, and the aggregation of sectors could be addressed using MU-hLCA.

To demonstrate the flexibility and practicality of MU-hLCA, it is applied in case studies on recycled construction materials and by-products. By using MU-hLCA, all phases including the use, disposal and recycling stages can be represented in physical units, allowing specific products such as RCA, FA, GGBFS, $\mathrm{NaOH}, \mathrm{Na}_{2} \mathrm{SiO}_{3}$, and iron and steel scrap to be applied in this study without altering the aggregated IOT sectors. GHGE reductions of (1) $1 \%$ is observed when $100 \%$ of RCA replace NA (gravel) in both GPC and OPC concrete, (2) $30 \%$ can potentially be achieved with RCA GPC compared to NA OPC concrete, and (3) $43 \%$ is achieved via the EAF route compared to the BOF route. A comprehensive assessment of life cycle emissions of green and alternative materials using MU-hLCA is useful to inform the policies and best practices adopted in the Australian construction industry, making it an essential tool for the successful implementation of these principles by policymakers and the government.

A method to capture the physical flows of waste and recycled materials can be done with the WIO model, provided that detailed waste data is available. Whilst MU-hLCA 
does the same, it is not limited to waste and recycled materials. The high resolution of LCI processes in the process system of the MU-hLCA framework allows for the flexibility of other specific products or processes (e.g. specific chemicals) to be assessed.

Another important application of MU-hLCA is in studying circular economy that promotes the sustainable concept of make-use-reuse-recycle (Stahel 2016; Weisz et al. 2015), as it enables the modelling of life cycle emissions when virgin materials are substituted by recycled materials in an economy-wide scale. Circular economy can bring substantial benefits from the environmental, social, and economic points of view, where employment, welfare and gross domestic product could be enhanced (Breene 2016; McKinsey and Company 2016). China has recently decided to disallow imports of foreign waste from countries including Australia (Lasker et al. 2017). To overcome the negative implications of this new policy and to reduce reliance on external providers of waste management services, Australia needs to harness the benefits of reusing and recycling, and reinvigorate local recycling initiatives and transition to a circular economy. MU-hLCA contributes towards the efforts of quantifying the environmental benefits of recycled materials, and can potentially analyse the socioeconomic benefits as well, provided suitable satellite data are available.

Recommendations for future research include to further explore the usefulness of the downstream cut-off matrix for economy-wide scenario analysis, and for an assessment on potential GHGE reduction in the built environment. Various products not limited to construction materials such as recycling glass, paper, plastic and metals should be explored.

\section{Additional file}

Additional file 1. Additional information on "Mixed-unit hybrid life cycle assessment applied to the recycling of construction materials".

\section{Abbreviations}

GHGE: greenhouse gas emissions; C\&D: construction and demolition; IOT: input-output table; LCA: life cycle assessment; IOA: input-output analysis; MIOT: monetary input-output table; PIOT: physical input-output table; IO: input-output; LCl: life cycle inventory; MFA: material flow analysis; MU-hLCA: mixed-unit hybrid life cycle assessment; hLCA: hybrid life cycle assessment; MUIOT: mixed-unit input-output table; GPC: geopolymer concrete; EW-MFA: economy-wide material flow analysis; IO-hLCA: input-output-based hybrid life cycle assessment; CFI: carbon footprint intensity; WIO: waste inputoutput; SUT: supply-and-use table; $C^{d}$ : downstream cut-off matrix; $C^{\mathrm{u}}$ : upstream cut-off matrix; RA: recycled aggregate; RCA: recycled concrete aggregate; NA: natural (coarse) aggregate; OPC: ordinary Portland cement; FA: fly ash; GGBFS: ground granulated blast furnace slag; EAF: electric arc furnace; $\mathrm{BF}-\mathrm{BOF}$ : blast furnace-basic oxygen furnace; $\mathrm{CH}_{4}$ : $\mathrm{meth}$ ane; $\mathrm{N}_{2} \mathrm{O}$ : nitrous oxide; $\mathrm{CO}_{2}$ : carbon dioxide; $\mathrm{CO}_{2}$-eq: carbon dioxide equivalents; AusLCl: Australian Life Cycle Inventory; IELab: Australian Industrial Ecology Virtual Laboratory; RoW: rest-of-the-world; $\mathrm{NaOH}$ : sodium hydroxide; $\mathrm{Na}_{2} \mathrm{SiO}_{3}$ : $\mathrm{SOdium}$ silicate; SI: supplementary information; $\mathrm{m}_{\mathrm{MUH}}$ : total impact multipliers; VA: value added; FD: final demand; EPDs: Environmental Product Declarations; GWP: global warming potential.

\section{Authors' contributions}

SHT wrote the manuscript in consultation with TW and SM. All authors read and approved the final manuscript.

\section{Author details}

1 Sustainability Assessment Program (SAP), School of Civil and Environmental Engineering, University of New South Wales, Sydney, NSW 2052, Australia. ${ }^{2}$ Integrated Sustainability Analysis (ISA), School of Physics A28, The University of Sydney, Sydney, NSW 2006, Australia.

\section{Acknowledgements}

The authors would like to thank Man Yu from UNSW Sydney for her help in the construction of the upstream cut-off matrix. The authors are grateful to Shinichiro Nakamura for his discussions regarding the WIO model. 


\section{Competing interests}

The authors declare that they have no competing interests. Author Thomas Wiedmann is also an Editor of the Journal of Economic Structures.

\section{Availability of data and materials}

The process and input-output datasets employed in this article are available from AusLCI (http://www.auslci.com.au/) and IELab (https://ielab.info), respectively.

\section{Ethics approval and consent to participate}

Not applicable.

\section{Funding}

This research is funded by the CRC for Low Carbon Living Ltd supported by the Cooperative Research Centres program, an Australian Government initiative (Project ID RP2007).

\section{Publisher's Note}

Springer Nature remains neutral with regard to jurisdictional claims in published maps and institutional affiliations.

Received: 20 December 2017 Accepted: 1 June 2018

Published online: 15 June 2018

\section{References}

ABARES (2010) Australian commodity statistics 2010. Department of Agriculture and Water Resources, Canberra, Australia. http://www.agriculture.gov.au/abares/publications/display?url=http://143.188.17.20/anrdl/DAFFService/ display.php?fid=pe_abares99001762.xml. Accessed 15 Jan 2016

ABS (2013) Waste account, Australia, experimental estimates. Australian Bureau of Statistics, ACT, Australia. http://www. abs.gov.au/AUSSTATS/abs@.nsf/DetailsPage/4602.0.55.0052013?OpenDocument. Accessed 11 April 2016

ACOR (2015) Australian scrap market analysis. Australian Council of Recycling, Australia. http://www.acor.org.au/uploa ds/2/1/5/4/21549240/acor_scrap_market_analysis.pdf. Accessed 5 July 2017

Altimiras-Martin A (2014) Analysing the structure of the economy using physical input-output tables. Econ Syst Res 26:463-485. https://doi.org/10.1080/09535314.2014.950637

AusLCI (2015) The Australian life cycle inventory database initiative. Australian Life Cycle Assessment Society, Australia. http://alcas.asn.au/AusLCI/index.php/Datasets/Materials. Accessed 30 July 2015

Australasian EPD (2015a) Environmental product declaration for steel—hot rolled coil. BlueScope Steel Limited, Melbourne, Australia. http://www.steel.com.au/articles/environmental-product-declarations. Accessed 15 May 2016

Australasian EPD (2015b) Environmental product declaration for steel—welded beams and columns. BlueScope Steel Limited, Melbourne, Australia. http://www.steel.com.au/articles/environmental-product-declarations. Accessed 15 May 2016

Australasian EPD (2015c) Environmental product declaration for XLERPLATE steel. BlueScope Steel Limited, Melbourne, Australia. http://www.steel.com.au/articles/environmental-product-declarations. Accessed 15 May 2016

Bailey R, Allen JK, Bras B (2004) Applying ecological input-output flow analysis to material flows in industrial systems: part I: tracing flows. J Ind Ecol 8:45-68

Berndt ML, Sanjayan J, Foster S, Castel A (2013) Pathways for overcoming barriers to implementation of low CO2 concrete. CRC For Low Carbon Living. http://www.lowcarbonlivingcrc.com.au/sites/all/files/publications_file_attac hments/rp1004_low_carbon_concrete_report.pdf. Accessed 10 April 2016

Björkman B, Samuelsson C (2014) Chapter 6—recycling of steel. In: Handbook of recycling. Elsevier, Boston, pp 65-83. https://doi.org/10.1016/b978-0-12-396459-5.00006-4

Braunschweig A, Kytzia S, Bischof S (2011) Recycled concrete: environmentally beneficial over virgin concrete? Paper presented at the life cycle management conference 2011 -towards life cycle sustainability management, Berlin, Germany, 28-31 Aug 2011

Breene K (2016) Can the circular economy transform the world's number one consumer of raw materials? World Economic Forum https://www.weforum.org/agenda/2016/05/can-the-circular-economy-transform-the-world -s-number-one-consumer-of-raw-materials/. Accessed 10 April 2018

Brunner PH, Rechberger H (2004) Practical handbook of material flow analysis. Int J Life Cycle Assess 9:337-338

Bullard CW, Herendeen RA (1975) The energy cost of goods and services. Energ Policy 3:268-278

Burchart-Korol D (2013) Life cycle assessment of steel production in Poland: a case study. J Clean Prod 54:235-243. https ://doi.org/10.1016/j.jclepro.2013.04.031

CCAA (2008) Use of recycled aggregates in construction. Cement Concrete \& Aggregates Australia, NSW, Australia. http:// www.ccaa.com.au. Accessed 17 May 2017

Cencic O, Rechberger H (2008) Material flow analysis with software STAN. Environ Eng Manag J 18:3

Choi T, Jackson RW, Leigh NG, Jensen CD (2011) A baseline input_output model with environmental accounts (IOEA) applied to e-waste recycling. Int Reg Sci Rev 34:3-33. https://doi.org/10.1177/0160017610385453

CoogeeChemicals (2016) Chlor-alkali plant in Kwinana, WA. http://www.coogee.com.au/Our-Businesses/ChemicalsManufacturing/Manufacturing-Facilities/Chlor-Alkali-Plant-in-Kwinana,-WA. Accessed 3 June 2016

Corder GD, Golev A, Giurco D (2015) "Wealth from metal waste": translating global knowledge on industrial ecology to metals recycling in Australia. Miner Eng 76:2-9. https://doi.org/10.1016/..mineng.2014.11.004

Crawford RH (2008) Validation of a hybrid life-cycle inventory analysis method. J Environ Manag 88:496-506. https://doi. org/10.1016/j.jenvman.2007.03.024 
Crawford RH, Bontinck P-A, Stephan A, Wiedmann T (2017) Towards an automated approach for compiling hybrid life cycle inventories. Procedia Eng 180:157-166. https://doi.org/10.1016/j.proeng.2017.04.175

Crawford RH, Bontinck P-A, Stephan A, Wiedmann T, Yu M (2018) Hybrid life cycle inventory methods - a review. J Clean Prod 172:1273-1288. https://doi.org/10.1016/j.jclepro.2017.10.176

CSIRO (2002) HB 155-2002: guide to the use of recycled concrete and masonry materials. Commonwealth Scientific and Industrial Research Organisation (CSIRO), Australia

Davidovits J (2015) False values on $\mathrm{CO}_{2}$ emission for geopolymer cement/concrete published in scientific papers. Geopolymer Institute, Saint-Quentin, France. http://www.geopolymer.org/library/technical-papers/false-co2-value s-published-in-scientific-papers/. Accessed 17 Jan 2016. Technical Paper \#24

Ding GKC (2014) 3-life cycle assessment (LCA) of sustainable building materials: an overview. In: Pacheco-Torgal F, Cabeza LF, Labrincha J, Magalhães Ad (eds) Eco-efficient construction and building materials. Woodhead Publishing, pp 38-62. https://doi.org/10.1533/9780857097729.1.38

Dixit MK (2017) Embodied energy analysis of building materials: an improved IO-based hybrid method using sectoral disaggregation. Energy 124:46-58. https://doi.org/10.1016/j.energy.2017.02.047

Energetics (2012) Steel stewardship forum—Australian steel chain footprint project. Energetics, North Sydney, NSW, Australia. file:///C:/Users/z5033911/Downloads/media-File-SSF_Australian_Steel_Chain_Footprint_FINAL_v402. pdf. Accessed 10 May 2017

Fry J, Lenzen M, Giurco D, Pauliuk S (2016) An Australian multi-regional waste supply-use framework. J Ind Ecol 20:12951305. https://doi.org/10.1111/jiec.12376

Galvin B, Lloyd N (2011) Fly ash based geopolymer concrete with recycled concrete aggregate. Paper presented at the proceedings of the CONCRETE 2011 Conference, Perth, WA, Australia, 12 Oct 2011

Giljum S, Hubacek K (2004) Alternative approaches of physical input-output analysis to estimate primary material inputs of production and consumption activities. Econ Syst Res 16:301-310. https://doi.org/10.1080/095353104200023 9383

Golev A, Corder G (2016) Modelling metal flows in the Australian economy. J Clean Prod 112:4296-4303. https://doi. org/10.1016/j.jclepro.2015.07.083

Grant T (2015) Life cycle inventory of cement \& concrete produced in Australia. Life Cycle Strategies Pty Ltd, Melbourne, Australia. www.dropbox.com/s/yrldimoqifemikh/Cement\%20concrete\%20LCl\%20Report\%20F1_3.pdf?dl=0. Accessed 30 July 2015

Habert G, Ouellet-Plamondon C (2016) Recent update on the environmental impact of geopolymers. RILEM Tech Lett 1:17-23

Habert G, d'Espinose de Lacaillerie JB, Roussel N (2011) An environmental evaluation of geopolymer based concrete production: reviewing current research trends. J Clean Prod 19:1229-1238. https://doi.org/10.1016/j.jclep ro.2011.03.012

Hawkins TR (2007) A mixed-unit input-output model for life cycle assessment: development, uncertainty, and application. Ph.D. Dissertation, Carnegie Mellon University

Hawkins T, Hendrickson C, Higgins C, Matthews HS, Suh S (2007) A mixed-unit input-output model for environmental life-cycle assessment and material flow analysis. Environ Sci Technol 41:1024-1031. https://doi.org/10.1021/es060 $871 \mathrm{u}$

Hoekstra R, van den Bergh JCJM (2006) Constructing physical input-output tables for environmental modeling and accounting: framework and illustrations. Ecol Econ 59:375-393. https://doi.org/10.1016/j.ecolecon.2005.11.005

Hyder Consulting (2009) Waste ferrous metal in Australia_estimate of steel disposed to landfill. Hyder Consulting, North Sydney, Australia. http://steel.org.au/media/File/Hyder_Report_Australian_Steel_in_LandfillFINAL.pdf. Accessed 3 May 2017

Hyder Consulting (2011a) Construction and demolition waste status report, management of construction and demolition waste in Australia. Hyder Consulting, Encycle Consulting \& Sustainable Resource Solutions, Melbourne, Australia. http://www.environment.gov.au/system/files/resources/323e8f22-1a8a-4245-a09c-006644d3bd51/files/ construction-waste.pdf. Accessed 29 May 2017

Hyder Consulting (2011 b) Waste and recycling in Australia 2011: incorporating a revised method for compiling waste and recycling data. Department of Sustainability, Environment, Water, Population and Communities, ACT, Australia. http://www.environment.gov.au/protection/national-waste-policy/publications/waste-and-recycling-austr alia-2011. Accessed 28 May 2017

Kleijer AL, Lasvaux S, Citherlet S, Viviani M (2017) Product-specific life cycle assessment of ready mix concrete: comparison between a recycled and an ordinary concrete. Resour Conserv Recycl 122:210-218. https://doi.org/10.1016/j. resconrec.2017.02.004

Knoeri C, Sanyé-Mengual E, Althaus H-J (2013) Comparative LCA of recycled and conventional concrete for structural applications. Int J Life Cycle Assess 18:909-918. https://doi.org/10.1007/s11367-012-0544-2

Kucukvar M, Egilmez G, Tatari O (2014) Evaluating environmental impacts of alternative construction waste management approaches using supply-chain-linked life-cycle analysis. Waste Manag Res 32:500-508. https://doi. org/10.1177/0734242×14536457

Lasker P, Goloubeva J, Birtles B (2017) China's ban on foreign waste leaves Australian recycling industry eyeing opportunities. http://www.abc.net.au/news/2017-12-10/china-ban-on-foreign-rubbish-leaves-recycling-industry-in-amess/9243184. Accessed 11 Dec 2017

Lenzen M (2000) Errors in conventional and input-output-based life-cycle inventories. J Ind Ecol 4:127

Lenzen M, Reynolds CJ (2014) A supply-use approach to waste input-output analysis. J Ind Ecol 18:212-226. https://doi. org/10.1111/jiec.12105

Lenzen M, Geschke A, Wiedmann T, Lane J, Anderson N, Baynes T, Boland J, Daniels P, Dey C, Fry J, Hadjikakou M, Kenway S, Malik A, Moran D, Murray J, Nettleton S, Poruschi L, Reynolds C, Rowley H, Ugon J, Webb D, West J (2014) Compiling and using input-output frameworks through collaborative virtual laboratories. Sci Total Environ 485-486:241-251. https://doi.org/10.1016/j.scitotenv.2014.03.062 
Lenzen M, Geschke A, Malik A, Fry J, Lane J, Wiedmann T, Kenway S, Hoang K, Cadogan-Cowper A (2017) New multiregional input-output databases for Australia_enabling timely and flexible regional analysis. Econ Syst Res 29:275-295. https://doi.org/10.1080/09535314.2017.1315331

LeontiefW (1970) Environmental repercussions and the economic structure: an input-output approach. The review of economics and statistics 262-271

Liang S, Zhang T (2013) Investigating reasons for differences in the results of environmental, physical, and hybrid inputoutput models. J Ind Ecol 17:432-439. https://doi.org/10.1111/jiec.12010

Limbachiya M, Meddah MS, Ouchagour Y (2012) Use of recycled concrete aggregate in fly-ash concrete. Constr Build Mater 27:439-449. https://doi.org/10.1016/j.conbuildmat.2011.07.023

Majeau-Bettez G, Wood R, Hertwich EG, Strømman AH (2016) When do allocations and constructs respect material, energy, financial, and production balances in LCA and EEIO? J Ind Ecol 20:67-84. https://doi.org/10.1111/ jiec.12273

Marinković S, Radonjanin V, Malešev M, Ignjatović I (2010) Comparative environmental assessment of natural and recycled aggregate concrete. Waste Manag 30:2255-2264. https://doi.org/10.1016/j.wasman.2010.04.012

Marinković S, Dragaš J, Ignjatović I, Tošić N (2017) Environmental assessment of green concretes for structural use. J Clean Prod 154:633-649. https://doi.org/10.1016/j.jclepro.2017.04.015

Mayer H, Flachmann C (2011) Extended input-output model for energy and greenhouse gases. Federal Statistical Office (Statistisches Bundesamt), Environmental-Economic Accounting, Wiesbaden, Germany. https://www.destatis.de/ EN/Publications/Specialized/EnvironmentalEconomicAccounting/ExtendedlnputOutputModel.pdf?_blob=publi cationFile Accessed 13 Feb 2017

Mcllvin K (2015) Low carbon alternatives for steel in Australia's construction industry. Honours Thesis, The University of New South Wales

McKinsey \& Company (2016) The circular economy: Moving from theory to practice. McKinsey \& Company. https://www. mckinsey.com/ /media/McKinsey/Business\%20Functions/Sustainability\%20and\%20Resource\%20Productivity/ Our\%20Insights/The\%20circular\%20economy\%20Moving\%20from\%20theory\%20to\%20practice/The\%20circular\%20economy\%20Moving\%20from\%20theory\%20to\%20practice.ashx. Accessed 10 April 2018

McLellan BC, Williams RP, Lay J, van Riessen A, Corder GD (2011) Costs and carbon emissions for geopolymer pastes in comparison to ordinary portland cement. J Clean Prod 19:1080-1090. https://doi.org/10.1016/j.jclep ro.2011.02.010

Miller D, Doh J-H, Mulvey M (2015) Concrete slab comparison and embodied energy optimisation for alternate design and construction techniques. Constr Build Mater 80:329-338. https://doi.org/10.1016/..conbuildmat.2015.01.071

Nakamura S, Kondo Y (2002) Input-output analysis of waste management. J Ind Ecol. https://doi.org/10.1162/10881 9802320971632

Nakamura S, Kondo Y (2006) A waste input-output life cycle cost analysis of the recycling of end-of-life electrical home appliances. Ecol Econ. https://doi.org/10.1016/j.ecolecon.2005.05.002

Nakamura S, Kondo Y (2009) Waste input-output analysis: concepts and application to industrial ecology. Springer, New York. https://doi.org/10.1007/978-1-4020-9902-1

Nakamura S, Nansai K (2016) Input-output and hybrid LCA. In: Finkbeiner M (ed) Special types of life cycle assessment. Springer, Dordrecht, pp 219-291. https://doi.org/10.1007/978-94-017-7610-3_6

Net Balance (2012) The Australian recycling sector. Department of Sustainability, Environment, Water, Population and Communities (DSEWPaC), Australia. http://www.environment.gov.au/system/files/resources/dc87fd71-6bcb4135-b916-71dd349fc0b8/files/australian-recycling-sector.pdf Accessed 3 June 2017

Norgate TE, Jahanshahi S, Rankin WJ (2007) Assessing the environmental impact of metal production processes. J Clean Prod 15:838-848. https://doi.org/10.1016/j.jclepro.2006.06.018

Olmez GM, Dilek FB, Karanfil T, Yetis U (2016) The environmental impacts of iron and steel industry: a life cycle assessment study. J Clean Prod 130:195-201. https://doi.org/10.1016/j.jclepro.2015.09.139

Orica (2016) Former chloralkali plant remediation project overview. http://www.orica.com/Locations/Asia-Pacific/Austr alia/Botany/Botany-Transformation-Projects/Mercury-Remediation/former-chloralkali-plant-remediation-proje ct-overview\#.WdRH81uCyM8. Accessed 3 June 2016

Peters GP, Hertwich EG (2006) A comment on "functions, commodities and environmental impacts in an ecological-economic model". Ecol Econ 59:1-6. https://doi.org/10.1016/j.ecolecon.2005.08.008

Productivity Commission (2006) Waste management, report no. 38. Australia Government Productivity Commission, Canberra, Australia. http://www.pc.gov.au/_data/assets/pdf_file/0014/21614/waste.pdf. Accessed 9 May 2017

Reynolds CJ, Piantadosi J, Boland J (2014) A waste supply-use analysis of Australian waste flows. Econ Struct 3:5. https:// doi.org/10.1186/s40008-014-0005-0

Säynäjoki A, Heinonen J, Junnonen J-M, Junnila S (2017) Input-output and process LCAs in the building sector: Are the results compatible with each other? Carbon Manag. https://doi.org/10.1080/17583004.2017.1309200

Senaratne S, Lambrousis G, Mirza O, Tam VWY, Kang W-H (2017) Recycled concrete in structural applications for sustainable construction practices in Australia. Procedia Eng 180:751-758. https://doi.org/10.1016/j.proeng.2017.04.235

Shan X, Zhou J, Chang VWC, Yang E-H (2017) Life cycle assessment of adoption of local recycled aggregates and green concrete in Singapore perspective. J Clean Prod 164:918-926. https://doi.org/10.1016/j.jclepro.2017.07.015

Stahel WR (2016) Circular economy: a new relationship with our goods and materials would save resources and energy and create local jobs. Nature 531:435-439

Suh S (2004) Functions, commodities and environmental impacts in an ecological-economic model. Ecol Econ 48:451-467

Suh S (2006) Reply: downstream cut-offs in integrated hybrid life-cycle assessment. Ecol Econ 59:7-12. https://doi. org/10.1016/j.ecolecon.2005.07.036

Suh S (2011) The structure of life-cycle environmental impact of the US economy. Paper submitted for the 2011 Leontief Prize by $\| \mathrm{OA}$

Suh S, Lenzen M, Treloar GJ, Hondo H, Horvath A, Huppes G, Jolliet O, Klann U, Krewitt W, Moriguchi Y, Munksgaard J, Norris G (2004) System boundary selection in life-cycle inventories using hybrid approaches. Environ Sci Technol 38:657-664. https://doi.org/10.1021/es0263745 
Tam VWY (2008) Economic comparison of concrete recycling: a case study approach. Resour Conserv Recycl 52:821-828. https://doi.org/10.1016/j.resconrec.2007.12.001

Tam VWY (2009) Comparing the implementation of concrete recycling in the Australian and Japanese construction industries. J Clean Prod 17:688-702. https://doi.org/10.1016/j.jclepro.2008.11.015

Tam VWY, Lo CY, Xiao J (2013) Bringing recycled aggregate to its full potential. Proc Inst Civ Eng Waste Resour Manag 166:128-136. https://doi.org/10.1680/warm.12.00020

Tam VWY, Soomro M, Evangelista ACJ (2018) A review of recycled aggregate in concrete applications (2000-2017). Constr Build Mater 172:272-292. https://doi.org/10.1016/j.conbuildmat.2018.03.240

Teh SH, Wiedmann T (2017) Decomposition of integrated hybrid life cycle inventories by industry, product and process Sustainability Assessment Program (SAP), Water Research Centre, School of Civil and Environmental Engineering, UNSW Sydney, Australia. http://www.wrc.unsw.edu.au/sustainability. Accessed 12 Dec 2017

Teh SH, Wiedmann T, Castel A, de Burgh J (2017) Hybrid life cycle assessment of greenhouse gas emissions from cement, concrete and geopolymer concrete in Australia. J Clean Prod 152:312-320. https://doi.org/10.1016/j.jclep ro.2017.03.122

Torres A, Brandt J, Lear K, Liu J (2017) A looming tragedy of the sand commons. Science 357:970-971. https://doi. org/10.1126/science.aao0503

Tošić N, Marinković S, Dašić T, Stanić M (2015) Multicriteria optimization of natural and recycled aggregate concrete for structural use. J Clean Prod 87:766-776. https://doi.org/10.1016/j.jclepro.2014.10.070

Turner LK, Collins FG (2013) Carbon dioxide equivalent $\left(\mathrm{CO}_{2}-\mathrm{e}\right)$ emissions: a comparison between geopolymer and OPC cement concrete. Constr Build Mater 43:125-130. https://doi.org/10.1016/j.conbuildmat.2013.01.023

Vendries Algarin J, Hawkins TR, Marriott J, Khanna V (2016) Effects of using heterogeneous prices on the allocation of impacts from electricity use: a mixed-unit input-output approach. J Ind Ecol. https://doi.org/10.1111/jiec.12502

Wan Omar W-M-S, Doh J-H, Panuwatwanich K (2014) Variations in embodied energy and carbon emission intensities of construction materials. Environ Impact Assess Rev 49:31-48. https://doi.org/10.1016/j.eiar.2014.06.003

Warrian P (2016) A profile of the steel industry: global reinvention for a new economy, second edition vol Second edition. Industry profiles collection. Business Expert Press, New York, New York [222 East 46th Street, New York, NY 10017]

Weisz H, Duchin F (2006) Physical and monetary input-output analysis: What makes the difference? Ecol Econ 57:534541. https://doi.org/10.1016/j.ecolecon.2005.05.011

Weisz H, Suh S, Graedel TE (2015) Industrial ecology: the role of manufactured capital in sustainability. Proc Natl Acad Sci 112:6260-6264. https://doi.org/10.1073/pnas.1506532112

Wiedmann T (2017) On the decomposition of total impact multipliers in a supply and use framework. Econ Struct 6:11. https://doi.org/10.1186/s40008-017-0072-0

Wiedmann T, Suh S, Feng K, Lenzen M, Acquaye A, Scott K, Barrett JR (2011) Application of hybrid life cycle approaches to emerging energy technologies - the case of wind power in the UK. Environ Sci Technol 45:5900-5907

Wijayasundara M, Mendis P, Zhang L, Sofi M (2016) Financial assessment of manufacturing recycled aggregate concrete in ready-mix concrete plants. Resour Conserv Recycl 109:187-201. https://doi.org/10.1016/j.resconrec.2016.02.007

Wijayasundara M, Crawford R, Mendis P (2017a) Comparative assessment of embodied energy of recycled aggregate concrete. J Clean Prod 152:406-419. https://doi.org/10.1016/j.jclepro.2017.03.118

Wijayasundara M, Mendis P, Crawford R (2017b) Methodology for the integrated assessment on the use of recycled concrete aggregate replacing natural aggregate in structural concrete. J Clean Prod 166:321-334. https://doi. org/10.1016/j.jclepro.2017.08.001

WSA (2015) Sustainable steel policy and indicators 2015. World Steel Association, Brussels, Belgium. https://www.world steel.org/en/dam/jcr:9fbd1018-62ac-4175-bc92-abff4715a748/Sustainable+Steel+-+Policy+and+Indicators +2015.pdf. Accessed 21 June 2017

Yellishetty M, Ranjith PG, Tharumarajah A (2010) Iron ore and steel production trends and material flows in the world: Is this really sustainable? Resour Conserv Recycl 54:1084-1094. https://doi.org/10.1016/.jesconrec.2010.03.003

Yellishetty M, Mudd GM, Ranjith PG, Tharumarajah A (2011) Environmental life-cycle comparisons of steel production and recycling: sustainability issues, problems and prospects. Environ Sci Policy 14:650-663. https://doi.org/10.1016/j. envsci.2011.04.008

Yu M, Wiedmann T, Crawford R, Tait C (2017) The carbon footprint of Australia's construction sector. Paper presented at the International High-Performance Built Environments Conference 2016, Sydney, Australia, 18-19 Nov 2016

\section{Submit your manuscript to a SpringerOpen ${ }^{\circ}$ journal and benefit from:}

- Convenient online submission

- Rigorous peer review

- Open access: articles freely available online

- High visibility within the field

- Retaining the copyright to your article

Submit your next manuscript at $>$ springeropen.com 